\title{
LA VISIÓN DE SANTO DOMINGO DE SILOS: ONIROCRÍTICA Y SEMÁNTICA
}

\author{
JAVIER ROBERTO GONZÁLEZ \\ Universidad Católica Argentina \\ Consejo Nacional de Investigaciones Científicas y Técnicas (Argentina)
}

A Aquilino Suárez Pallasá, maestro generoso

$y$ discreto, con indecible gratitud.

\section{RESUMEN}

Estudiamos la visión profética de Santo Domingo de Silos en la Vida de Santo Domingo de Silos de Gonzalo de Berceo, con el objeto de: a) analizar el texto según las categorías de profecía, visión y sueño vigentes en la cultura cristiana medieval; b) analizar la configuración de las imágenes oníricas como discurso alegórico; c) dados los límites de la semántica alegórica, interpretar aquellas imágenes simbólicas caracterizadas por la obscuritas profética a la luz de la Vita Beati Dominici de Grimaldo, fuente de la Vida de Berceo, y también a la luz de la tradición medieval de las visiones de trasmundo y del simbolismo general cromático y aritmético, en orden al establecimiento de las innovaciones semánticas y con ellas del recto sentido del texto de Berceo.

Palabras clave: Berceo, profecía, visión, sueño, alegoría, símbolo.

\begin{abstract}
We study the prophetic vision of Santo Domingo de Silos in Gonzalo de Berceo's Vida de Santo Domingo de Silos, with the aim of: a) analysing the text according to categories of prophecy, vision and dream in medieval christian culture; b) analysing the configuration of oniric images as an allegorical discourse; c) given the limits of allegorical semantics, interpreting those symbolic images characterized by prophetical obscuritas in the light of Grimaldus' Vita Beati Dominici, source of Berceo's Vida, and also in the light of medieval tradition of Other World visions and general chromatic an arithmetical symbolism, in order to establish semantic innovations and the proper meanning of Berceo's text.
\end{abstract}

Key words: Berceo, prophecy, vision, dream, allegory, symbol.

\section{INTRODUCCIÓN}

Los cuatro santos a quienes dedicó Gonzalo de Berceo una vida - San Millán de la Cogolla, Santo Domingo de Silos, Santa Oria, San Lorenzo-, poseen el don de la profecía, de la visión, o ambos. El poeta parece entender las dos facultades como distintas, según se desprende de lo que 
afirma de Santo Domingo de Silos en dos pasajes del poema correspondiente:

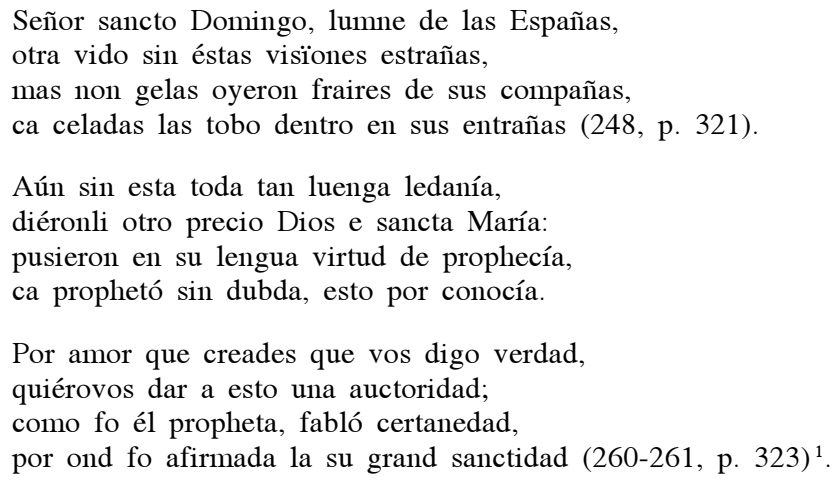

Según se deduce de ambas citas, el poeta identifica la visión con un acto puramente cognoscitivo, que excluye la comunicación simultánea de lo habido en revelación divina por el santo - aunque bien pueda admitir una comunicación posterior que resulta ya distinta del acto visionario en sí-, y la profecía con un acto locutivo en el que el conocimiento revelado fluye verbalmente en el mismo momento de su donación divina ${ }^{2}$. Por nuestra parte, y en línea con la concepción medieval más consagrada tal como la expone Santo Tomás de Aquino, preferimos incluir la visión como una especie dentro del género de la profecía, y definir a esta última no necesariamente ni principalmente como locución, sino como el conocimiento, verbalizado o no, de verdades objetivas ocultas al entendimiento natural de uno, varios o todos los hombres, ya por defecto de la facultad cognoscitiva humana, ya por incognoscibilidad intrínseca de las verdades en cuestión; así, mediante la definición del acto profético como conocimiento y del objeto de dicho acto como verdad en sentido lato, quedan desechadas dos concepciones frecuentes y populares, pero con toda evidencia erróneas, de la profecía: la que identifica forzosamente a ésta con una proferición verbal de lo conocido, y la que limita el objeto del conocimiento a verdades referidas a una instancia temporal futura. Santo Tomás lo deja en claro al establecer que la profecía «primo et principaliter consistit in cognitione», y sólo «secundario consistit in locutione, prout prophetae ea quae divinitus edocti cognoscunt, ad aedificationem aliorum annuntiant»(S.Theol., II-II, q. 171, a. 1; cfr. DEVINE, «Pro-

${ }^{1}$ Todas nuestras citas de la Vida de Santo Domingo de Silos proceden de la edición de Aldo Ruffinatto incluida en la Obra completa de Berceo coordinada por Isabel Uría.

2 También la crítica berceana que se ha ocupado de estos temas separa como experiencias distintas la visión y la profecía, enumerándolas junto a los milagros como las tres formas de lo sobrenatural propias de los poemas hagiográficos del autor; $c f r$. BALESTRINI, «Si cosa de Dios eres...», 151-160; BAÑOS VALLEJO, «Lo sobrenatural», 21-32. 
phecy», 473-474; MiCHEL, «Prophétie», 709, 714-715); más adelante, al sentar que lo que la profecía conoce como su objeto propio son «quaedam quae sunt procul remota ab hominum cognitione» (II-II, q. 171, a. 1), especifica la naturaleza de esos remota distinguiendo tres clases de objetos proféticos: lo que está fuera del conocimiento de un hombre determinado mas no de todos, lo que está fuera del conocimiento de todos los hombres por defecto de la naturaleza humana, y lo que está fuera del conocimiento de todos los hombres por tratarse de una realidad de suyo incognoscible; sólo esta tercera y última clase de objetos proféticos se identifican con los futuros contingentes $^{3}$. Siendo entonces toda profecía un acto de conocimiento, la visión debe incluirse en aquélla como una especie caracterizada por su condición puramente mental, frente a la condición eventualmente verbal de las profecías proferidas; podemos por lo tanto distinguir, ajustando debidamente nuestra terminología, dentro del género de la profecía entendida como conocimiento lato, dos especies: la de las profecías mentales, consistentes en pura cognitio, y la de las profecías verbales, consistentes en cognitio et locutio; la especie de las profecías mentales, a su vez, bien puede dividirse en la subespecie de las profecías mentales en vigilia o pensamientos proféticos, y la subespecie de las profecías mentales oníricas o sueños proféticos ( $c f r$. S.Theol., II-II, q. 173, a. 2; DEVINE, «Prophecy», 474; GONZÁLEZ, «Pautas», 111-112; «Los sueños», 205-210; IMSCHOOT, «Profeta», 1577; LÉONDUFOUR, Vocabulario, 559; LESÊTRE, «Songe», 1832-1834; MANGENOT, «Prophétie», 729-730; Michel, «Prophétie», 713; «Songe», 2366; SouVAY, «Dreams», 154-156); tendremos ya ocasión de deslindar, a propósito de esta última categoría, cómo se relacionan y distinguen los conceptos de sueño y visión.

Sobre la base de los principios teóricos arriba esbozados, hemos de estudiar la visión profética de Santo Domingo de Silos, tal como la relata Berceo en las cuadernas 225-247 de su poema, con el objeto de: a) analizar su fenomenología según las categorías inherentes a la profecía, la visión y el sueño

\footnotetext{
${ }^{3}$ «Horum autem est triplex gradus. Quorum unus est eorum quae sunt procul a cognitione huius hominis, sive secundum sensum sive secundum intellectum, non autem a cognitione omnium hominum. Sicut sensu cognoscit aliquis homo quae sunt sibi praesentia secundum locum, quae tamen alius humano sensu, utpote sibi absentia, non cognoscit: et sic Eliseus prophetice cognovit quae Giezi, discipulus eius, in absentia fecerat, ut habetur II Reg. 5,26. Et similiter cogitationes cordis unius alteri prophetice manifestantur: ut dicitur I ad. Cor. 14,24. Et per hunc modum etiam ea quae unus scit demonstrative, alii possunt prophetice revelari. Secundus autem gradus est eorum quae excedunt universaliter cognitionem omnium hominum, non quia secundum se non sint cognoscibilia, sed propter defectum cognitionis humanae: sicut mysterium Trinitatis [...]. Ultimus autem gradus est eorum quae sunt procul ab omnium hominum cognitione, quia in seipsis non sunt cognoscibilia: ut contingentia futura, quorum veritas non est determinata» (II-II q. 171, a. 4; cfr. DEVINE, «Prophecy», 473-474; MiCHEL, «Prophétie», 709-715; MANGENOT, «Prophète», 705; «Prophétie», 728; GoNZÁLEZ, «Pautas», 108-110).
} 
de plena vigencia en la cultura cristiana medieval, vale decir, llevar a cabo una tarea de descripción e interpretación de naturaleza onirocrítica; b) a partir de los rasgos fenoménicos discernidos en relación con la obscuritas propia del género profético-visionario, analizar las imágenes oníricas en cuanto plasmación de un discurso alegórico; c) vistos los límites de la semántica alegórica, interpretar aquellas imágenes de índole simbólica que inequívocamente se resistan a una reducción alegorista a la luz del hipotexto de la Vita Beati Dominici de Grimaldo y de los datos textuales aportados por la tradición medieval de las visiones de trasmundo y del simbolismo general cromático y numérico, en orden al establecimiento de las innovaciones semánticas y con ellas del recto sentido del texto de Berceo ${ }^{4}$.

\section{LA VISIÓN ONÍRICA}

Entendido pues que el sueño profético es una subespecie de las profecías mentales, corresponde definir si tal subespecie se identifica, más o menos sinonímicamente, con la visión, o si ambos conceptos constituyen categorías distintas. Esta segunda alternativa aparece consagrada por Jacques Le Goff («Los sueños en la cultura», 286), que sienta una equivalencia simple y neta entre sueño = profecía mental onírica y visión = profecía mental en vigilia; se trataría, en definitiva, de asimilar la visión al conocimiento profético por sentidos externos, y el sueño al conocimiento profético por sentidos internos o por imaginativa, de acuerdo con la clasificación tomista: «Illa autem prophetia in qua manifestatur supernaturalis veritas per imaginariam visionem, diversificatur primo, secundum differentiam 'somnii', quod fit in dormiendo; et 'visionis', quae fit in vigilando» (S.Theol., II-II, q. 174, a. 3) ${ }^{5}$. Sin embargo, el mismo Le Goff abandona esta llana partición entre sueño/dormir y visión/velar y opta por una categorización distinta en un trabajo posterior («Le christianisme et les rêves», 256-316), donde parece identificar la vi-

${ }^{4}$ Ninguno de estos cometidos se propone ni lleva a cabo en su estudio dedicado a nuestro texto Frida Weber de Kurlat (WEBER DE KURLAT, «La 'visión' de Santo Domingo de Silos», 489-505).

${ }^{5}$ Santo Tomás distingue tres clases de conocer profético; el primero, identificable con la visión, opera a través de los sentidos externos en vigilia, el segundo, identificable con el sueño, opera a través de la imaginativa o los sentidos internos, y el tercero opera a través de la pura intelección o ciencia infusa: «Repraesentantur autem divinitus menti prophetae quandoque quidem mediante sensu exterius, quaedam formae sensibiles: sicut Daniel vidit scripturam parietis, ut legitur Dan. 5, 17 sqq. Quandoque autem per formas imaginarias: sive omnino divinitus impressas, non per sensum acceptas, puta si alicui caeco nato imprimerentur in imaginatione colorum similitudines; vel etiam divinitus ordinatas ex his quae a sensibus sunt acceptae, sicut Ieremias «vidit ollam succensam a facie Aquilonis», ut habetur Ier. 1, 13. Sive etiam imprimendo species intelligibiles ipsi menti: sicut patet de his qui accipiunt scientiam vel sapientiam infusam, sicut Salomon et Apostoli (III Reg 3, 5 et Act. 2)» (S.Theol., II-II, q. 173, a. 2). 
sión con un tipo de sueño profético claro, sin ambigüedades, y el sueño tout court con la profecía onírica de imágenes intrincadas y requeridas de interpretación ${ }^{6}$. Esta concepción de la visión como una especie del sueño, realizada a partir de la identificación visión = claridad $=$ univocidad y sueño $=$ oscuridad = ambigüedad, deriva finalmente, en razón de la fácil adscripción de lo claro y unívoco a un origen indudablemente divino y de lo oscuro y ambiguo a una condición falaz y engañosa, en una identificación de la visión con el sueño realmente profético, verdadero e inspirado por Dios, y que por serlo aparece como claro y diáfano en sus imágenes, y del sueño oscuro y ambiguo como una falsa profecía, engañosa y de origen no inspirado (ACEBRÓN RUIZ, Sueño y ensueños, 141-149). El propio Berceo parece convalidar esta última categorización, corriente en la Edad Media occidental, al nominar como visión el sueño de Santo Domingo, aclarando expresamente que fue habida mientras dormía: «El confessor glorioso, un cuerpo tan laçrado,/ duermiésse en su lecho, ca era muy cansado;/ una visión vido por ond fue confortado» (226a-c, p. 315). En la estrofa previa ya nos había certificado sobre el origen divino de la visión: «El Reï de los reyes porque tanto sufrié,/ bien gelo condessava quanto élli facié;/ por darli buen confuerto de lo que merecié,/ quísoli demostrar quál galardón avrié» (225a-d, p. 315); con todo, la visión de Domingo no conlleva ese carácter claro y diáfano al que aludíamos arriba, sino bien al contrario, se trata de un sueño que combina imágenes unívocas y expresamente explicadas, según la técnica alegórica, con otras de intrincado y oscuro simbolismo que paran en la oscuridad y la equivocidad. Pero para dar debida cuenta del origen de esta concepción medieval de la visión como territorio de lo claro y del sueño como territorio de lo oscuro, que Berceo no respeta, se impone acudir a un autor de fines de la Antigüedad cuyo breve tratado de onirología habría de signar la idea del sueño a lo largo del medioevo; nos referimos a Macrobio y a sus Commentarii in Somnium Scipionis, que exponen la doctrina platónica del

${ }^{6}$ Un biblista veterotestamentario como André Neher distingue, a propósito de la oscuridad y la claridad proféticas, entre la profecía de ruah y la profecía de dabar. La ruah es el Espíritu, la revelación de visiones —oníricas o no- a veces equívocas o ambiguas, en tanto el dabar es la inspiración de palabras objetivas y unívocas: «[...] la visión pertenece al terreno de la ruah; es oscura, tiene necesidad de ser descifrada; y ese mismo desciframiento tiene que ser ratificado por Dios. La ruah es enigmática. Amós, Jeremías y Zacarías son preguntados por el sentido de sus visiones; se dice de ellos que han visto bien; podrían haber visto mal. Solamente en el momento en que Dios, en vez de hacer ver y sentir, habla, es cuando la verdad de la revelación queda definitivamente asentada. Para que al conocimiento se le asigne la autenticidad absoluta, es menester que la ruah cristalice en el dabar. La palabra es la madurez del espíritu»(NEHER, La esencia del profetismo, 98). Como se ve, el deslinde de Nerher no apunta tanto a una identificación del sueño con lo oscuro y la visión con lo claro, como en Le Goff, sino del sueño y la visión en su conjunto, en cuanto profecías mentales, con lo oscuro, y de la profecía verbal con lo claro. 
alma, Dios y el mundo según se contiene en el Somnium Scipionis de Cicerón, pero que incluyen asimismo, a modo de urgido prólogo a su análisis del sueño ciceroniano, consideraciones teóricas acerca de los sueños en general, sus distintas clases y especies y el mayor o menor valor revelatorio de cada una de éstas (GoNZÁlEZ, «Los sueños», 210-214). Distingue allí cinco diversitates et nomina de sueños:

[...] quinque sunt principales et diversitates et nomina. aut enim est óneiros secundum Graecos quod Latini somnium vocant, aut est hórama quod visio recte appellatur, aut est chrematismós quod oraculum nuncupatur, aut est enýpnion quod insomnium dicitur, aut est phántasma quod Cicero, quotiens opus hoc nomine fuit, visum vocavit (A. T. MACROBIUS, Commentarii, I.3.2).

Las dos últimas clases discernidas no son proféticas ni interpretables: el insomnium no es más que una vaga reminiscencia durante el sueño de los deseos o inquietudes de la vigilia (I.3.4-6), y el visum la generación de imágenes durante un estado fronterizo de duermevela (I.3.7); el oraculum, en cambio, sí es plenamente profético, y consiste en la aparición, dentro del sueño, de un personaje grave que vaticina verbalmente ${ }^{7}$; en cierto modo, se trata de una profecía verbal inserta en una profecía mental onírica. En cuanto a la visio y al somnium, que son las dos categorías que más nos interesan, la definición de Macrobio apunta a la ya mencionada identificación de la primera con las imágenes claras y unívocas y del segundo con las imágenes oscuras, equívocas y necesitadas de interpretación: «visio est autem cum id quis videt quod eodem modo quo apparuerat eveniet» (I.3.9); el soñador comprende por sí mismo lo que ha de sucederle, mediante la visión de imágenes oníricas que se corresponden exacta y unívocamente con los hechos futuros a los que aluden y que en virtud de su claridad resultan instantáneamente inteligibles sin la intervención de intérpretes. El caso del somnium es muy otro, pues las imágenes son en él equívocas y confusas, y ocultan su significado mediante ambages que imponen como imprescindible el concurso de un intérprete:

somnium proprie vocatur quod tegit figuris et velat ambagibus non nisi interpretatione intellegendam significationem rei quae demonstratur, quod quale sit non a nobis exponendum est, cum hoc unus quisque ex usu quid sit agnoscat (I.3.10).

Lo cierto es que el sueño de Santo Domingo, tal como lo refiere Berceo y más allá de la terminología empleada por éste, resulta una mezcla de visio, somnium y oraculum. El soñante se descubre de pronto en un locus eremus donde destaca la presencia de un río pavoroso que se divide en dos brazos, uno blanco como cristal y el otro rojo como vino, y sobre el cual cruza un frágil y angosto puente de vidrio:

7 «et est oraculum quidem cum in somnis parens vel alia sancta gravisve persona seu sacerdos vel etiam deus aperte eventurum quid aut non eventurum, faciendum vitandumve denuntiat» (I.3.8). 
Vedíame en sueños en un fiero logar,

oriella de un flumen tan fiero como mar, quiquiere avrié miedo por a él se plegar, ca era pavoroso e bravo de passar.

Ixién délli dos ríos, dos aguas bien cabdales, ríos eran muy fondos, non pocos regajales, blanco era el uno como piedras cristales, el otro plus vermejo que vino de parrales.

Vedía una puente enna madre primera, avié palmo e medio ca más ancha non era, de vidrio era toda, non de otra madera, era, por no mentirvos, pavorosa carrera (229-231, pp. 315-317).

Del otro lado del río y del puente, dos hombres de blanco esperan a Domingo con tres coronas lucientes que le enseñan, y lo incitan a cruzar:

Con almátigas blancas de finos ciclatones, en cabo de la puent estavan dos barones, los pechos ofresados, mangas e cabeçones, non dizrién el adobo loquele nec sermones.

La una destas ambas tan onradas personas tenié enna su mano dos preciosas coronas, de oro bien obradas, omne non vio tan bonas, ni un omne a otro non dio tan ricas donas.

El otro tenié una seis tantos más fermosa, que tenié en su cerco mucha piedra preciosa, más lucié que el sol tant era de lumnosa, nunqua ome de carne vido tan bella cosa

Clamóme el primero que tenié las dobladas, que passasse a ellos, entrasse por las gradas; díxeli yo que eran aviessas las passadas, dixo él que sin dubda entrasse a osadas (232-235, p. 317).

Pese a la estrechez y la debilidad del puente, el santo logra atravesarlo y es recibido por los dos hombres de blanco: «Metíme por la puente, maguer estrecha era,/ passé tan sin embargo como por grand carrera,/ recibiéronme ellos de fermosa manera,/ veniendo contra mí por media la carrera» (236, p. 317). Los hombres le explican entonces que las tres coronas que portan le están destinadas por Dios como premio eterno: la primera por haber sido monje casto y obediente, la segunda por su devoción mariana tal como quedó manifiesta en su ministerio en Santa María de Cañas, la tercera por haber hecho resurgir el Monasterio de Silos:

«Aquestas que tú vedes coronas tan onradas, nuestro Señor las tiene pora ti condesadas, cata que no las pierdas quando las has ganadas, ca querrié el dïablo avértelas furtadas.» 
Díxelis yo: «Señores, por Dios que me oyades, por qué viene aquesto que vos me lo digades, yo non so de tal vida nin fiz tales bondades, la raçón de la cosa vos me la descubrades.»

«Bona raçón demandas», dixo el mensagero, «a esso te daremos responso bien certero: la una porque fuste casto e buen claustrero, a la obediencia non fuste refertero.

La otra te ganó mieña Sancta María, porque la su eglesia consagró la tu guía, en el su monesterio fecist grand mejoría, es mucho tu pagada, ende te la embía.

Esta otra tercera de tan rica facienda, por esti monesterio que es en tu comienda, que andava en yerro como bestia sin rienda, has tú sacado ende pobreça e contienda.

Si tú perseverares en las mañas usadas, tuyas son las coronas, ten que las as ganadas; avrán por ti repaire muchas gentes lazradas, que vernán sin consejo, irán aconsejadas» (238-243, p. 319).

Queda pues claro qué tiene este sueño de visio, de somnium y de oraculum. Tiene de visio lo que corresponde a las imágenes explicadas según la técnica alegórica, básicamente, las tres coronas que significan el premio eterno en el Paraíso para el santo; tiene de somnium lo que radica en las imágenes del lugar yermo, el río con sus dos brazos de diversos colores y el puente de vidrio, que constituyen símbolos de difícil y no explícita interpretación; tiene de oraculum lo que se contiene en el discurso verbal de los dos hombres de blanco que toman a su cargo la explicación de la alegoría de las tres coronas ${ }^{8}$. Adviértase por lo demás, a este último respecto, que es precisamente el oraculum de los dos hombres de blanco el sitio donde radica la «claridad» de la imagen de las tres coronas, y no tanto en la propia imagen; hay, por tanto, una recíproca potenciación de visio y oraculum que radica y opera en este último, el cual recoge y completa a la primera para llevarla a su máxima potencia semántica. El oraculum es a un tiempo la

\footnotetext{
${ }^{8}$ Además de la ya explicada clasificación de los sueños en insomnium, visum, visio, somnium y oraculum, Macrobio ofrece otra tipología, también quíntuple, atendiendo ahora a las species del sueño, que puede ser proprium, alienum, commune, publicum o generale: "proprium est cum se quis facientem patientemve aliquid somniat, alienum cum alium, commune cum se una cum alio, publicum est cum civitati forove vel theatro seu quibuslibet publicis moenibus actibusve triste vel laetum quid aestimat accidisse, generale est cum circa solis orbem lunaremve globum seu alia sidera vel caelum omnesve terras aliquid somniat innovatum» (I.3.11). El sueño de Domingo sería proprium, porque el santo se sueña a sí mismo y conoce su propio futuro.
} 
parte final y conclusiva del sueño y la parte que corona su sentido mediante la explicitación del más importante de sus contenidos, el que refiere la salvación del santo y su recompensa en la vida futura ${ }^{9}$; podemos entonces, finalmente, comprender y explicarnos por qué Berceo ha denominado visión al sueño en su integridad, pese a las imágenes oscuras y no explicitadas del río y el puente ${ }^{10}$ : se trata, en definitiva, de una nominación sinecdótica de pars pro toto, que impone el nombre de visión a la totalidad del sueño porque tal es la parte final y principal de él, aquella conclusiva que da cuenta del principal de los anuncios, al que se subordinan adjetivalmente todos los otros que lo preceden, esto es, de la salvación y la recompensa eterna de Domingo. Quedando clara y unívocamente expresada la parte central del vaticinio, éste puede reputarse como visio pese a que otras de sus partes y otros de sus anuncios entrañen una cierta oscuridad. Pero si bien, como decíamos, en esta parte final el oraculum recoge e integra a la visio para hacer explícito el significado de sus imágenes, los alcances del oraculum van bastante más allá de la explicación de las imágenes de la visio, pues incluye anuncios no relacionados con éstas ni encaminados a su interpretación: «Si tú perseverares en las mañas usadas,/ tuyas son las coronas, ten que las as ganadas;/ avrán por ti repaire muchas gentes lazradas,/ que vernán sin consejo, irán aconsejadas» $\left(243\right.$, p. 319) ${ }^{11}$. Anuncios, también ellos, claros y diáfanos, que marcan la necesaria trascendencia al prójimo de los efectos positivos de la gracia concedida al santo. Pero existen otros anuncios, en esa primera parte claramente clasificable como somnium según la nomenclatura de Macrobio, que no son tan claros ni diáfanos, y que sí requieren de una interpretación que no brindan ni el oraculum de los dos hombres de blanco ni se infiere sin riesgo de yerro a partir de las imágenes mismas: ¿qué son y qué significan el locus eremus con su río, qué la bifurcación de

\footnotetext{
${ }^{9}$ Se trata, por lo tanto, de una profecía pospectiva cuya verificación se encargará de narrar el macrotexto cuando dé cuenta de la muerte del santo y la llegada de su alma al cielo, donde en efecto es recibida y premiada con las tres coronas vaticinadas: «Prisiéronla los ángeles que estavan redor,/ leváronla a cielos e a muy grand onor,/ diéronli tres coronas de muy gran resplendor,/ desuso vos fablamos de la su gran lavor» (522, p. 389).

10 También Grimaldo, en su Vita Beati Dominici que Berceo utilizó como fuente, denomina visio a la totalidad del sueño de Domingo, cuando hace decir a este mismo en el momento de narrar su experiencia: «Videbam —inquit- in visione hac nocte me iuxta quendam fluvium stare...» (apud DUTTON [ed.], Obras completas IV [de Berceo]: La vida de Santo Domingo de Silos, 204).

${ }^{11}$ En cierto modo, los dos versos finales de la cuaderna amplían nuestra inicial catalogación del sueño de Domingo como proprium hasta convertirlo también en alienum, dado que si bien lo que principalmente conoce el santo en la visión onírica es su propio futuro de salvación, sabe también por las palabras del oraculum que la suerte de muchas otras personas habrá de remediarse o mejorarse gracias a él; la inidentificación de estas personas y la generalidad del anuncio, con todo, hacen que el aspecto alienum del sueño quede fuertemente restringido y prevalezca siempre su fuerte condición de proprium.
} 
ese río en dos brazos de color rojo como vino y blanco como cristal, qué el angosto puente de vidrio? ${ }^{12}$

\section{LOS LÍMITES DE LA ALEGORÍA}

Algunos críticos han considerado sin más como una alegoría el sueño de Santo Domingo. Rafael Sala lo consagra como «la única visión alegórica plenamente desarrollada en la Vida» (La lengua y el estilo, 97), y Post, en su clásico estudio sobre la alegoría en la literatura española medieval, lo considera como una muestra de técnica alegórica más perfecta y madura que la de la Introducción de los Milagros de Nuestra Señora, por cuanto a diferencia de ésta la alegoría de Domingo aparece mejor integrada en el cuerpo de la obra y entreteje más diestramente el elemento explicativo ${ }^{13}$. Esta opinión de Post no deja de sorprender, pues hemos visto que la única imagen alegórica en efecto explicada es la de las coronas, en tanto las previas del río y el puente quedan huérfanas de toda exégesis. Con todo, no cabe dudar acerca de la condición alegórica del sueño; más aun, considerando que su contenido refiere escatológicamente el más allá, podría inclusive entendérselo como un ejemplo de lo que en su momento definió Garrido Gallardo, a propósito de los Milagros, como un orden lineal de la trascendencia, por el cual la alegoría es empleada como medio discursivo que viene a significar que «la relación inmanencia-trascendencia es un continuum ordenado», y que «muestra lingüísticamente la linealidad sin falla del mundo de acá abajo y del de allá arriba» (GARRIDO GALLARDO, «Una clave», 281-282).

Concédase, pues, la índole alegórica del sueño de Domingo. Pero procédase debidamente a delimitar el recto concepto de alegoría, empleado por los medievales de manera tan frecuente como equívoca. Puede ayudar, al menos para un primer deslinde conceptual y terminológico, el recurso a una distinción que no procede del Medioevo, pero que ha arraigado fuertemente en el instrumental metodológico de la exégesis de obras medievales; se trata de la conocida contraposición de los términos alegoría y símbolo sancionada por Goethe, según la cual la primera se caracteriza por su sentido monosémico y transparente, plenamente racional, y por un modus denotativo que parte de una idea abstracta y desciende luego a la plasmación sensible

${ }^{12}$ Para mayores datos de naturaleza histórico-teórica en relación con los sueños, su significado y su construcción formal y funcional en la Edad Media, pueden consultarse los trabajos de Spearing (Medieval Dream Poetry), Kruger (Dreaming in the Middle Ages) y Gregory (I sogni nel medioevo).

${ }_{13}$ «The vision of the three crowns in the Vida de Santo Domingo de Silos [...] is an artistic entity wherein the allegorical narrative is sustained to the end and its exegesis inextricably woven into the fabric. The more skilful tratment of allegory would tend to discredit the view of Amador de los Ríos, who, following Sánchez, believes this the earliest of Berceo's poems» (POST, Mediaeval Spanish Allegory, 118; vid. también 10-11).

RLit, 2007, julio-diciembre, vol. LXIX, n. ${ }^{\circ} 138,411-447$, ISSN: 0034-849 
radicada en un objeto concreto, en tanto el segundo presenta un sentido polisémico y opaco, esquivo a toda reducción puramente racional ${ }^{14}$, y se construye mediante un movimiento inverso al de la alegoría, esto es, partiendo de un objeto material sensible al que se le adjudica luego como significado uno o varios valores inmateriales o ideas (GONZÁLEZ, «La alegoría», 37-38; TODOROV, Teorías del símbolo, 279-309) ${ }^{15}$. En línea con esta tópica distinción, podría decirse que en el sueño de Domingo hay una primera parte construida sobre la base de imágenes opacas, polisémicas e irreductibles a una interpretación racional unívoca - el locus eremus con el río bifurcado y el puente-, que consisten por ello mismo en símbolos y configuran lo que Macrobio define como somnium, y una segunda parte construida sobre la base de una imagen transparente, monosémica y racionalmente interpretada en forma expresa - las tres coronas-, que consiste

${ }^{14}$ «[...] el aspecto significante se penetra de inmediato en virtud del conocimiento de lo significado en la alegoría, mientras que en el símbolo el significante conserva su valor, su opacidad. Otras diferencias que no creemos innecesario recordar son las siguientes: el carácter transitivo de la alegoría en oposición al carácter intransitivo del símbolo. La alegoría significa directamente, es decir que no tiene otra razón de ser que transmitir un sentido, mientras que el símbolo significa indirectamente: en principio es por sí mismo. Mientras la alegoría se vincula con el concepto, el símbolo se vincula con la idea; mientras la alegoría es decible, el símbolo es indecible; en tanto el sentido de la primera es finito, el del segundo es infinito [...]. Sin entrar en pormenores disquisitivos teóricos que aquí no interesan, baste tener presente que el símbolo es, en tanto la alegoría significa; el primero fusiona significante y significado, la segunda los separa [...]. A pesar de la diversidad de teorías sobre el símbolo, parece indudable que todos los autores coinciden en la polivalencia de sentido que le es inherente, es decir que el símbolo 'no posee potestad significativa para un solo nivel sino que la tiene para todos los niveles'» (CVITANOVIC, De Berceo a Borges, 11-12).

${ }_{15}$ «Allegory starts with an idea and creates an imaginary object as its exponent. If one starts with an actual object and from it receives the suggestion of an idea, one is a symbolist. The primary difference between symbolism and allegory is that the former sees 'sermons in stones'; the latter from phantom stones builds sermons» (POST, Medieval Spanish Allegory, 4-5). Cfr. LEWIS, La alegoría del amor, 38: «Se podría, por un lado, comenzar por un hecho inmaterial, las pasiones que uno experimenta, por ejemplo, e inventar visibilia para expresarlas. Si uno vacilara entre una réplica airada y una respuesta amable, podría expresar ese estado de ánimo inventando un personaje que porta una antorcha, al que se llamaría Ira, y hacerlo disputar con otro personaje, también de ficción, al que se llamaría Patientia. Esto es alegoría [...]. Pero hay una manera distinta de tratar esa equivalencia, una manera casi opuesta a la de la alegoría, a la que yo llamaría sacramentalismo o simbolismo. Si las pasiones inmateriales son susceptibles de ser copiadas por ficciones materiales, quizá fuera también posible que el mundo material mismo fuera a su vez copia del mundo invisible. Lo que el dios Amor y su jardín de ficción son a las pasiones de los hombres quizá seamos nosotros mismos y nuestro mundo real a algo distinto [...]. Para expresar la diferencia en otros términos: para el simbolista, nosotros mismos somos alegoría. Nosotros somos las frías personificaciones; los altos cielos las vagas abstracciones; el mundo que tomamos por realidad, un simple esbozo de aquel que en otro sitio se encuentra en toda la plenitud de sus inimaginables dimensiones.» 
en una alegoría con sus dos clásicas partes de presentación de la imagen y explicación interpretativa, coincidentes aquí, respectivamente, con los dos tipos oníricos macrobianos de la visio y el oraculum. Alegoría y símbolo conviven y en cierto modo combaten por la exacta demarcación de sus límites y áreas, pues, en el sueño de Domingo, y en el preciso punto donde la alegoría acaba con su claro y único significado explícitamente expuesto, allí ha de comenzar la siempre riesgosa labor de interpretación de los opacos y múltiples valores de las imágenes simbólicas.

Pero el caso es que, como decíamos, esta distinción tan neta entre alegoría y símbolo no remonta más atrás del siglo XVIII; el pensamiento medieval no separaba en forma tan tajante ambos conceptos, o en todo caso los superponía parcialmente (ECO, Arte y belleza, 73-74). Básicamente, el símbolo era para la Edad Media un fenómeno del mundo más que del discurso, el modo de significar propio de la naturaleza y sus objetos o de la historia y sus hechos en cuanto escritura de Dios (ECO, Arte y belleza, 70), y en tal sentido podía identificarse con la denominada allegoria in factis vel historiae, mientras que la alegoría propiamente dicha, esto es, la allegoria in verbis vel sermonis, era sí un fenómeno discursivo ${ }^{16}$. Pero tanto el símbolo cuanto la alegoría, vale decir, tanto la alegoría en los hechos o de la historia cuanto la alegoría en las palabras o del discurso, eran fenómenos semióticos igualmente decodificables mediante la razón, reductibles a concepto ${ }^{17}$, transparentes y monosémicos ${ }^{18}$. Hay, por lo demás, un tercer con-

16 «Sea cual sea su naturaleza, esta tipología prevé ya que lo que es figurado (o tipo, o símbolo, o alegoría) es una alegoría que no concierne al modo en que el lenguaje representa a los hechos, sino que concierne a los hechos mismos. Se aborda aquí la diferencia entre allegoria in verbis y allegoria in factis. No es la palabra de Moisés o del Salmista, como palabra, la que hay que leer como dotada de sobresentido, aunque así habrá que hacer cuando se reconozca que es palabra metafórica: son los acontecimientos mismos del Antiguo Testamento los que han sido predispuestos por Dios, como si la historia fuera un libro escrito por su mano, para actuar como figuras de la nueva ley» (ECO, Arte y belle$z a, 80-81 ;$ cfr. 83, 87-88, 91).

17 «Así se comprende cómo y por qué este modo de hablar, que el mismo Dionisio llama 'simbólico' [...], no tiene nada que ver con esa iluminación, ese éxtasis, esa visión rápida y fulgurante que toda teoría moderna del simbolismo ve como propia del símbolo. El símbolo medieval es un modo de acceso a lo divino, pero no es epifanía de lo numinoso ni nos revela una verdad que pueda declararse sólo en términos de mito y no en términos de discurso racional. Es más, se trata del vestíbulo del discurso racional y su tarea (me refiero al discurso simbólico) es justo la de poner en evidencia, en el momento en el que resulta didascálica y vestibularmente útil, la propia inadecuación, el propio destino [...] de recibir su legitimación de un discurso racional sucesivo» (ECO, Arte y belleza, 77).

${ }^{18}$ La monosemia del símbolo medieval, con todo, no supone estrictamente la postulación de un único significado para cada signo, sino de un único significado para cada signo en un determinado nivel de interpretación, según la teoría de las correspondencias entre los distintos niveles o planos de lectura; así, una rosa significará la belleza femenina en un nivel antropológico, la belleza de la creación en un nivel cosmológico y la belleza increada o divina en un nivel teológico, pero siempre significará lo mismo y sólo eso en cada ni- 
cepto que enriquece todavía más el sistema de semiosis propio de las representaciones medievales: el de figura o tipo. La figura consiste en una forma o especie de alegoría - in factis o in verbis- por la cual una cosa, un hecho o una palabra del Antiguo Testamento, en virtud de una analogía o semejanza de forma o estructura, representan una cosa o un hecho del Nuevo Testamento, o bien una cosa, un hecho o una palabra del Nuevo Testamento representan una cosa o un hecho predicables del fin de los tiempos, vale decir, una realidad escatológica (ECO, Arte y belleza, 80-81; AUERBACH, Figura, 67-108). La figura pasa a operar, por tanto, como una construcción a la vez retórica y profética, pues su referencia consiste siempre en una verdad arcana y futura, que se tiende entre los polos de una primera figuración en el AT, una segunda figuración y primera consumación en el NT y una definitiva consumación en el fin de los tiempos ${ }^{19}$; la figura se define entonces como imago vel umbra, y la consumación como veritas; siendo, por lo demás, que la imago figural se construye, como queda dicho, sobre un hecho histórico o una formulación verbal, la figura actúa como cabal intermediaria entre la historia o la littera y la veritas (AUERBACH, Figura, 90-91). Originalmente este esquema de organización semiótica se aplicó a ambos Testamentos y a la Escatología por ellos profetizada directa o indirectamente, pero analógicamente se pasó luego a aplicar las mismas categorías a textos profanos o al menos no revelados; tal ocurre cuando Dante propone una lectura de su Commedia según los cuatro sentidos de la Escritura; éstos, por cierto, no hacen otra cosa que desarrollar los tres polos implícitos en la representación figural mediante el añadido de un cuarto sentido moral, de modo tal que el sentido literal corresponde a la formulación de la figura en el AT, el tipológico a su primera consumación en el NT, el anagógico a su definitiva consumación en el fin de los tiempos, y el moral a su aplicación cotidiana como norma en la vida de los hombres (S.Theol., I, q. 1., a. 10; cfr. TODOROV, Simbolismo, 123-131; AUERBACH, Figura, 84-85; DE BRUYNE, Estudios, II, 316-384).

De acuerdo con el modelo dantesco de la extensión de la semiosis figural a textos no escriturarios, bien podríamos postular la condición de figura para

vel. Los símbolos medievales están, como se ve, debidamente codificados según tradición, pero la codificación misma contempla la existencia de los diversos planos interpretativos y sus debidas correspondencias.

19 «La profecía figural implica la interpretación de un proceso universal y terrenal por medio de otro; el primer proceso significa el segundo, y éste consuma aquél. Ambos continúan siendo sucesos acontecidos en el interior de la historia; pero en esta concepción los dos suponen algo provisional e incompleto, se refieren mutuamente el uno al otro y señalan hacia un futuro inminente que será el acontecimiento pleno, real y definitivo. Esto no sólo resulta válido para el Antiguo Testamento, que anuncia la Encarnación y proclama el Evangelio, sino también para éstos, pues en ellos no tiene lugar la consumación última, sino la promesa del fin de los tiempos y del verdadero reino de Dios» (AUERBACH, Figura, 106; vid. también 83). 
el sueño de Santo Domingo, y más en concreto predicarle un sentido anagógico a partir de su referencia a realidades escatológicas; cierto es que la escatología del sueño de Domingo no remite al fin de los tiempos sino a la muerte y a la gloria individuales y personales del propio soñante, pero la referencia escatológica no desaparece por ello, y un sagaz estudioso de la técnica figural como Erich Auerbach parece sugerir que para postular la existencia de una figura, más allá de la naturaleza escrituraria del discurso en cuestión o inclusive de la referencia al fin de los tiempos, basta con que se cumplan al menos dos condiciones, a saber, que el discurso refiera inequívocamente un objeto histórico - no abstracto- de consumación futura, y que posea un claro sentido religioso-cristiano (AUERBACH, Figura, 93-115). Ambas condiciones se cumplen en el texto de Berceo, que retendremos pues como figural según esta última caracterización amplísima, y como alegórico al mismo tiempo, dado que, muy frecuentemente, los términos allegoria y figura se identificaban sinonímicamente en el lenguaje medieval ${ }^{20}$.

Ahora bien, la alegoría en cuanto representación figurada, según la clásica definición de aliud dicitur, aliud demonstratur, remite necesariamente a una explicación o declaración de las imágenes o verba impropia mediante los cuales indirectamente se refiere la realidad representada; dicha explicación o declaración puede incluirse en forma explícita dentro del discurso alegórico, o bien puede callársela y darla por supuesta, dejándola librada al buen entendimiento de los lectores; en el primer caso, la explicación puede acompañar una por una la presentación de cada imagen, o bien remitirse en bloque para el final del discurso, después de presentadas todas las imágenes de la alegoría. Es esta última posibilidad la que se considera, según la teoría, una alegoría perfecta ${ }^{21}$, en tanto las otras dos modalidades — sea la ausencia de explicación expresa ${ }^{22}$, sea la explicación paulatina que acompaña a cada imagen ${ }^{23}$ - entrañan formas de alegoría imperfecta. Queda claro que el sueño de Domingo debe catalogarse como una alegoría imperfecta por ausencia de explicación expresa, o en todo caso, por ausencia casi total de dicha explicación —little interpretation, en términos de Post—, pues la única imagen explicada, la de las coronas, resulta insuficiente para la comprensión acabada de la alegoría en su totalidad. Ésta, con todo, y pese a la dificultad que deriva de su condición de imperfecta, resulta pasible de ser

${ }^{20}$ Por caso, en Santo Tomás y su ya aludida formulación de los cuatro sentidos de la escritura (S.Theol., I, q. 1., a. 10; cfr. TODOROV, Simbolismo, 123-125).

${ }^{21}$ «The first [way of handling the allegorical material] is somewhat crude: the allegorical fiction is relegated to a short introduction, and the later and principal part of the composition is an exegesis of this fiction»(POST, Mediaeval Spanish Allegory, 42).

${ }^{22}$ «In the second manner of presentation, the allegory is maintained throughout with little or no interpretation» (POST, Mediaeval Spanish Allegory, 47).

${ }^{23}$ «A third and less frequent mode of presentation [...] is to define the symbol as soon as it is mentioned»(Post, Mediaeval Spanish Allegory, 50). 
comprendida, ya que no mediante una explicación completa y explícita, al menos mediante una interpretación contextual o relacional de sus imágenes no declaradas. Porque dos son, al menos, los modos de una imagen de definir su sentido; según el primero de esos modos, que llamaríamos referencial, la imagen deriva su sentido directamente de la referencia al objeto real que designa, referencia que o bien se hace explícita en la declaración alegórica o bien se infiere a partir de una lectura interpretativa de la imagen misma en relación con la tradición o los hábitos literarios consagrados; según el segundo modo, que llamamos estructural o relacional - y por ello plenamente semiótico-, la imagen deriva su sentido a partir de la relación sintagmática o sintáctica que establece con las imágenes contiguas de la alegoría y de sus respectivos sentidos ${ }^{24}$. En consecuencia, si se trata en nuestro caso de definir el significado del río y el puente en la alegoría imperfecta del sueño de Santo Domingo, nos es lícito recurrir, para una definición relacional, al significado de la imagen contigua y explicada de las tres coronas, y para una definición referencial a la tradición de las visiones medievales donde aquellas mismas imágenes aparecen y se explican. Con respecto a la definición relacional, queda claro que si las coronas son explícita representación alegórica de los premios que el santo ha de recibir en la vida eterna, y tales coronas se ubican en su representación imaginal al cabo de un río peligroso y un puente frágil y angosto, que deben atravesarse no sin riesgo para llegar hasta ellas, el cruce del río a través del puente debe alegorizar el paso de la vida terrena a la vida eterna a través de la muerte, la gran barrera humana cargada del mayor riesgo objetivo y del condigno temor subjetivo por la incertidumbre que plantea acerca del destino ulterior de salvación o condena. Pero aunque inexcusable, la interpretación relacional no resulta suficiente para la acabada definición de las imágenes del río y el puente, porque se limita a aclararnos el sentido de éstas en cuanto sustancias primarias y nada nos dice en cambio sobre esas otras imágenes secundarias que dependen de aquéllas como los accidentes de las sustancias, y que son el vidrio de la materia del puente, el blanco y el rojo de la cualidad cromática del río, y la cantidad binaria de los dos brazos en que se bifurca éste. Es precisamente para acceder a una definición adecuada de estos tres accidentes de materia, cualidad y cantidad que se hace necesario intentar una interpretación referencial de las imágenes, lo cual obliga a trascender el contexto meramente intratextual del sintagma alegórico del sueño de Domingo en busca del contexto extratextual de las alegorías visionarias de la Edad Media, y aun de ciertos arquetipos de la tradición simbólica universal.

${ }^{24}$ En trabajos anteriores hemos desarrollado y explicado estos dos modos de significación, referencial y relacional, a propósito del simbolismo numérico medieval (GONZÁLEZ, «El número como símbolo», 89-118). 


\title{
4. EL RÍO Y EL PUENTE
}

El marco inmediato y primero de una recta interpretación contextual extratextual de una alegoría berceana debe ser, siempre, su fuente latina directa, en este caso, la Vita Beati Dominici de Grimaldo. Veámosla:

\begin{abstract}
Videbam -inquit - in visione hac nocte me iuxta quendam fluvium stare, de quo fluvio emanabant duo magni rivi nimium profundi, unus retinens ad instar lactis colorem candidum, alter vero ad similitudinem sanguinis sanguineum, et dum ambo rivi de supradicto fluvio procedere michi videretur, alter tamen alteri non iungebatur. Super flumen vero videbatur michi esse pons vitreus spatium palmi et dimidii habens amplitudo illius, in cuius pontis extremitate stabant duo viri, ultra humanam pulcritudinem pulcerrimi, vestibus albis inducti, quorum pectora zonis aureis miro fulgore fulgentibus erant precinta et unus ex his duas coronas aureas nimio et incredibili splendore splendentes in manu tenebat, alter vero unam solam ferebat, que septemplici fulgore illas duas quas alter tenebat superabat et insuper tota ex lapidibus preciosis contexta erat, at ille qui duas coronas tenebat me vocabat et ut ad eos venirem iubebat, sed e contra me respondente ac dicente: «Non possum, domine, nimis certe angustus et fragilis est pons iste, quem omnino nequeo pertransire.» Respondens dixit michi: «Noli timere, sed securus libere transi et veni.» Cuius precepto obtenperans, prospero et innoffenso gradu, angustum et vitreum pontem transivi et ad eos veni [...] (apud DutTon, [ed.], Obras completas IV [de Berceo]: La vida de Santo Domingo de Silos, 204).
\end{abstract}

Una primera y obvia conclusión debería ser que tampoco Grimaldo explica la alegoría del puente y el río; sí explicará luego la que sigue de las tres coronas, de modo que, tanto en lo que calla cuanto en lo que dice, el poeta riojano no hace otra cosa sino respetar al máximo el esquema alegórico imperfecto de su fuente. Sin embargo, hay diferencias entre el hipotexto de Grimaldo y el hipertexto de Berceo, que entendemos ascienden a las siguientes tres: a) no existe en Grimaldo la imagen del locus eremus, que Berceo introduce como expansión locativa del río; b) si bien en ambos textos los colores de las dos bifurcaciones del río son el blanco y el rojo, cambian los términos de comparación e identificación, pues en Grimaldo el río blanco se compara con la leche y en Berceo con la piedra cristal, y el río rojo se compara en Grimaldo con la sangre y en Berceo con el vino de parrales; c) la tercera corona, que supera a las otras dos en resplandor, es siete veces más refulgente en Grimaldo, en tanto en Berceo lo es apenas seis veces. Sobre la primera de las tres diferencias cabe sólo decir que, más que una innovación plena de Berceo, el dato del locus eremus consiste en una simple expansión adjetivo-locativa del río, cuyo carácter fiero, temible y peligroso comparte y desarrolla a modo de marco espacial que amplía y por tanto intensifica dicha connotación. En cuanto a la tercera diferencia, que conlleva una modificación del simbolismo numérico, puede sorprender 
que Berceo resigne el prestigioso número siete de la fuente — de cuyas connotaciones simbólicas él mismo era, por lo demás, en extremo conscientepara sustituirlo por el senario en el hemistiquio «seis tantos más fermosa»; quizás sea la misma métrica la que nos dé una explicación, dada la necesidad de no sobrepasar la medida heptasilábica del hemistiquio, pero más probablemente -y repetimos, considerando la plena advertencia de los valores simbólicos numéricos que Berceo demuestra tener en sus obras- haya habido una voluntad de vincular aritméticamente la cuantificación de la mayor excelencia de la tercera corona con las otras dos cantidades involucradas en la imagen, vale decir, el binario de los dos hombres y de las otras dos coronas, y el ternario de las tres coronas en su totalidad, de modo que la tercera corona fundara su mayor belleza y esplendor en el producto de dos factores, a saber, los dos hombres o las dos coronas previas por las tres coronas totales: dos por tres, igual seis ${ }^{25}$. Se trata, naturalmente, de una conjetura indemostrable ${ }^{26}$.

Queda por analizar la tercera diferencia, la de los términos de comparación de los dos brazos, blanco y rojo, del río. Brian Dutton, apelando al tópico de la crítica que enfatiza la índole realista y expresiva de la poesía en general y de las comparaciones en particular de nuestro autor, arriesga la hipótesis de que la descripción berceana del río y sus dos brazos corresponda a la geografía real de Silos, donde en efecto existe, muy próximo a la abadía, un río formado a partir de la confluencia de otros dos que presentan

${ }^{25}$ El cambio del siete por el seis no implicaría mengua alguna en la intención de connotar perfección, pues ambos números, por razones distintas, son tenidos como perfectos por la tradición simbólica occidental. El siete lo es en cuanto suma del celeste tres más el terreno cuatro, y por su referencia a numerosas totalidades perfectas del mundo natural y cultural: planetas, días de la semana, artes liberales, virtudes naturales y teologales, pecados capitales, eras del mundo, etc.; el seis, si bien puede ser tenido por imperfecto en cuando defecto respecto del perfecto siete, es con frecuencia connotado como perfecto a causa de su condición de producto de los dos números básicos, el primer par y el primer impar (2x3), operatoria que según arriesgamos realiza aquí Berceo, y también por ser el primer número completo según la tradición del pitagorismo, vale decir, por resultar de la suma de los tres primeros números de la serie, que son además sus tres posibles divisores $(1+2+3)$. Cfr. S. Agustín, Civ. Dei, XI, 30-31, 638-641; CAPElla, De Nuptiis, VII, 370-373; S. ISIDORI Liber numerorum, VII-VIII, 185-186; H. DE S. VICTORE Exegetica I, 22-23; GONZÁLEZ, «El número como símbolo», 92-99; HOPPER, Medieval Number Symbolism, 37-47 et passim; BUTLER, Number Symbolism, 22-46).

${ }^{26}$ Pero no infundada. Como queda dicho, Berceo es consciente usuario de símbolos numéricos en sus obras, y muy en especial del septenario al que aquí renuncia; el total de cuadernas de la Vida de Santo Domingo es 777, el de Los Signos del Juicio Final, 77, y cada uno de los tres Himnos presenta 7 estrofas; en los Loores de Nuestra Señora, por lo demás, el poeta realiza una expresa alabanza del número siete: «El cuento septenario es de grant santidad» (Obra completa, 143a y ss., pp. 907-909). En otras obras, como los Milagros de Nuestra Señora y Del Sacrificio de la Misa, aparecen claros símbolos numéricos, más o menos desarrollados. Cfr. ARTILES, Los recursos literarios, 232-235; GARIANO, Análisis estilístico, 122-123. 
en sus lechos, respectivamente, rocas blanquecinas y arenas rojizas ${ }^{27}$. La referencia al vino de parrales como término comparativo para el río rojo, en lugar de la sangre evocada por Grimaldo, respondería asimismo a la consabida tendencia de Berceo a realizar alusiones a las circunstancias concretas de su pago chico, donde en efecto el vino que se produce es siempre tinto ${ }^{28}$. No puede en absoluto descartarse la hipótesis de Dutton, por lo demás muy bien fundamentada, pero en todo caso cuadra recordar que más allá de toda mímesis realista o inclusive costumbrista el poeta ha llevado a cabo aquí una innovación semántica respecto de su fuente escrita, y lo ha hecho mediante una clara operación de resimbolización; no ha destruido ni reemplazado en su sustancia los símbolos de Grimaldo, pero mediante la parcial y acotada manipulación de las imágenes secundarias o accidentales de la cantidad y de la materia que funciona como término de comparación de los colores ha alterado en no pequeña medida el sentido global de la alegoría. Por otra parte, ténganse siempre en cuenta uno de los principios fundamentales de la concepción medieval del mundo como símbolo: símbolo y realidad, valor simbólico y designación real objetiva no sólo no se excluyen, sino antes bien se implican y potencian, de modo que todo símbolo requiere de la existencia real del elemento simbolizante para mejor fundar la debida relación analógica con el elemento simbolizado; así, cuanto mayor sea la entidad y la concreción del elemento real simbolizante —en nuestro caso, un par de ríos geográficamente existentes y localizables- más efectiva será la potencia del símbolo y más plena la definición de su sentido ${ }^{29}$. Es ésta,

27 «Esta visión corresponde a la geografía física de Silos. Es interesante notar que la abadía de Silos está situada en la ribera de un río formado por otros dos que confluyen corriente arriba del monasterio, cerca de un puente. Uno de estos ríos viene de hacia Carazo, llamado el Ura o Mataviejas, cuya madre está cubierta de rocas grisáceas y blanquecinas. El otro río, el del Santo, sale por una garganta estrecha en las rocas del valle donde nace. El suelo de este valle es muy arenoso, dando un color rojizo a la madre del río del Santo. Estas correspondencias tienen un enorme interés sicológico» (DUTTON, [ed.], Obras completas IV [de Berceo]: La vida de Santo Domingo de Silos, 164-165, n. 230[a]).

${ }^{28}$ «El vino de Silos, cuando se produce, ha sido siempre tinto» (DuTTON, [ed.], Obras completas IV [de Berceo]: La vida de Santo Domingo de Silos, 165, 1. 230[a]). «Sus comparaciones (y lo mismo diríamos del mundo de sus imágenes) tienen, por eso, un carácter descendente, de rebajamiento, de acercamiento a lo inmediato y cotidiano. Berceo quiere, con buen sentido pedagógico, que sus oyentes se eleven y asciendan a la comprensión de realidades superiores por la fácil escala de las cosas más familiares. Son cosas, a veces, humildes y caseras, elementales, como el pan y el vino, el azúcar, la miel, los ajos y el mortero, la sal» (ARTILES, Los recursos literarios, 124-125).

${ }^{29}$ «En effet, on a trop souvent tendance à penser que l'admission d'un sens symbolique doit entrâ̂ner le rejet du sens littéral ou historique; une telle opinion ne résulte que de l'ignorance de la loi de correspondence qui est le fondement même de tout symbolisme, et en vertu de laquelle chaque chose, procédant essentiellement d'un principe métaphysique dont elle tient toute sa réalité, traduit ou exprime ce principe à sa manière et selon son ordre d'existence, de telle sorte que, d'un ordre à l'autre, toutes choses s'enchainent et se 
pues, la tarea que nos resta, la definición acabada del sentido de la alegoría de Berceo a partir de la resimbolización operada por éste sobre el texto de su fuente, resimbolización consistente, según la nomenclatura retórica, en una doble operación de adiectio $^{30}$ —introducción del topos del locus eremus a modo de expansión adjetiva de la imagen nuclear del río peligroso y temible- y de immutatio $^{31}$ — sustitución de la cantidad septenaria por la senaria en relación con el resplandor de la tercera corona, de la leche por la piedra cristal como término de comparación para el color blanco de uno de los brazos del río, y de la sangre por el vino de parrales como término de comparación para el color rojo del otro brazo-. Se impone por tanto el análisis de esta resimbolización, pero es menester para ello proceder a ampliar el marco de nuestra interpretación, pasando de lo contextual extratextual inmediato que ofrecía el concreto hipotexto de la fuente de Grimaldo a lo contextual extratextual mediato que ofrece la entera tradición de las visiones alegóricas y demás aventuras maravillosas medievales que involucran riesgosos pasajes de puentes sobre temibles ríos ( $c f r$. PÉREZ PRIEGO, «Berceo y las postrimerías del hombre», 527-529). No podríamos, por cierto, agotar la inmensa lista potencial de estos textos; nos limitaremos por ello a una acotada serie de trece ejemplos que brindan un campo discursivo lo suficientemente amplio como para fundar toda ulterior interpretación contextual del sueño de Domingo. He aquí los textos:

[1] Visio Esdrae (época incierta). Esdras es llevado por los ángeles al infierno, donde encuentra un río de fuego y sobre éste un puente que los justos cruzan sin dificultad, pero no así los pecadores: «et pons iste reuertebatur in subtilitatem ut filum staminis et cadebant in hoc flumen confitentes pecata sua (apud PATCH, El otro mundo, 97).

[2] Visio Sancti Pauli (siglo III). Arrebatado en cuerpo y espíritu al tercer cielo, San Pablo contempla la Jerusalén Celestial ceñida por cuatro ríos, de leche, miel, aceite y vino; más adelante arriba a un río de fuego donde están sumergidos los pecadores hasta las rodillas, el vientre, los labios o la coronilla, según la grave-

correspondent pour concourir à l'harmonie universelle et totale, qui est, dans la multiplicité de la manifestation, comme un reflet de l'unité principielle elle même» (GuÉNON, Le symbolisme de la croix, 12). «Todavía recientemente, la vieja querella entre los 'simbolistas' y los 'realistas' ha estallado de nuevo a propósito de la arquitectura religiosa del antiguo Egipto. Las dos posiciones sólo son irreconciliables en apariencia [...]. El simbolismo añade un nuevo valor a un objeto o a una acción, sin que por ello queden afectados sus valores propios o inmediatos. Aplicándose a un objeto o a una acción, el simbolismo los 'abre'. El pensar simbólico hace 'estallar' la realidad inmediata, pero sin disminuirla ni desvalorizarla» (ELIADE, Imágenes y símbolos, 191; cfr. DE BRUYNE, Estudios, II, 317, 357-360; GONZÁLEZ, «Realismo y simbolismo», 16-18).

${ }^{30}$ «La adiectio [...] es la agregación al todo dado, por lo menos, de un nuevo elemento, que hasta ahora no pertenecía al todo» (LAUSBERG, Elementos, 45).

31 «La immutatio [...] es la sustitución por lo menos de un elemento, que hasta ahora pertenecía al todo, por otro elemento hasta ahora ajeno al mismo» (LAUSBERG, Elementos, 46). 
dad de sus faltas; sobre el río hay un puente: «Et desuper illud flumen est pons, per quem transeunt animae iuste sine ulla dubitacione, et multe peccatrices anime merguntur unaqueque secundum meritum suum. Ibi sunt multe bestie dyabolice multeque mansiones male preparate. Tantum uero potest quisque per pontem illum ire quantum habet meritum» (apud PATCH, El otro mundo, 101).

[3] Gregorio Magno. Dialogi (siglo VI). Un soldado, muerto y vuelto a su cuerpo poco después, relata su visión del infierno: «Aiebat enim, sicut tunc res eadem etiam multis innotuit, quia pons erat, sub quo niger atque caliginosus foetoris intolerabilis nebulam exhalans fluvius decurrebat. Transacto autem ponte, amoena erant prata atque virentia, odoriferis herbarum floribus exornata, in quibus albatorum hominum conventicula esse videbantur. [...] Haec vero erat in praedicto ponte probatio ut quisquis per eum vellet injustorum transire, in tenebrosum foetentemque fluvium laberetur; justi vero quibus culpa non obsisteret, securo per eum gressu ac libero ad loca amoena pervenirent» (GREGORIUS I MAGnus, Dialogi, PL, vol. LXXVII, cap. 36, cols. 384-385).

[4] Gregorio de Tours. Historia Francorum (siglo VI). El abad Sunniulfo tiene una visión del infierno: «Ipse quoque referre erat solitus, ductum se per visum ad quoddam flumen igneum, in quo ab una parte littoris concurrentes populi seu apes ad alvearia mergebantur: et erant alii usque ad cingulum, alii vero usque ad ascellas, nonnulli usque mentum, clamantes cum fletu se vehementer aduri Erat enim et fons [sic, id est pons] super fluvium positus ita angustus, ut vix unius vestigii latitudinem recipere posset. Apparebat autem et in alia parte littoris domus magna extrinsecus dealbata. Tunc iis qui cum eo erant, quid sibi haec velint interrogat. At illi dixerunt: De hoc enim ponte praecipitabitur, qui ad distringendum commissum gregem fuerit repertus ignavus; qui vero strenuus fuerit, sine periculo transit, et inducitur laetus in domum quam conspicis ultra» (GREGORIUS TURONENSIS, Historia Francorum, PL, vol. LXXI, pars IV, cap. 33, col. 174)

[5] Epístola XX de San Bonifacio (siglo VIII). San Bonifacio escribe a la abadesa Eadburga acerca de la visión de transmundo del monje de Wenlock: «Interea referebat se quasi in inferioribus in hoc mundo vidisse igneos puteos horrendam eructantes flammam plurimos, et erumpente terra terribilis flammae ignes volitasse, et miserorum hominum spiritus, in similitudine nigrarum avium, per flammam plorantes et ululantes, et verbis et voce humana stridentes, et lugentes propria merita, et praesens supplicium, consedisse paululum, haerentes in marginibus puteorum, et iterum ejulantes cecidisse in puteos. [...] Nec non et igneum piceumque flumen bulliens et ardens mirae formidinis et teterrimae visionis cernebat, super quod lignum pontis vice positum erat ad quod sanctae gloriosaeque animae ab illo secedentes conventu, properabant, desiderio alterius ripae, transire cupientes, et quaedam non titubantes constanter transibant; quaedam vero labefactae de ligno cadebant in tartareum flumen; et aliae tingebantur, quasi toto corpore mersae: aliae autem ex parte quadam veluti ad genua media, quaedam vero usque ad ascellas; et tamen unaquaeque cadentium multo clarior, speciosiorque de flumine in alteram ascendebat ripam, quam prius in piceum bulliens cecidisset flumen. [...] Et citra illud fumen speculatus muros fulgentes clarissimi splendoris, stupendae longitudinis, et altitudinis immensae, et sanctos angelos dixisse: Haec est enim illa sancta et inclyta civitas coelestis Jerusalem, in qua istae perpetualiter sanctae gaudebunt animae» (BONIFACIUS Moguntinus, Epistolae, PL, vol. LXXXIX, ep. XX, cols. 716-717).

[6] Visión irlandesa de San Adamnán (siglo XI). Adamnán es llevado en visión a las regiones infernales, donde encuentra «a glen full of fire. There was 
a huge blaze in it, so that it came out over its sides on either hand. Black were its depths, red its midst and its upper parts. Eight monsters were in it, their eyes like fiery lumps of molten metal. A huge bridge is across the glen; it reaches from one side to the other, high in the middle but low at each end. Three parties are attempting to go over it, and not all get across. One party, for them the bridge is wide from beginning to end, so that they cross it unhurt, without fear and without terror, over the fiery glen. Another party, however, as they approach it, it is narrow for them at first but wide at last, so that they cross in this way over that same glen after great peril. But the last party, for them the bridge is wide at first but narrow and strait at last, so that they fall from its midst into that same perilous glen, into the gullets of those eight fiery monsters which make their dwelling in the glen. The people for whom that road was easy, they are the virgins, the zealous penitents, the bloody martyrs desirous of God. The group for which the road was narrow at first and wide at last after that are the people who are forced to do the will of God, and convert their constraint afterwards into the willing service of God. But those for whom the bridge was wide at first and was narrow at last are the sinners who listen to the teaching of the word of God, and do not perform it when they have heard it» (A Celtic Miscellany, 292).

[7] Visión de Alberico (siglo XII). El monje benedictino Alberico, tras yacer nueve días como muerto, recibe la visita de una paloma, que le extrae el alma por la boca y lo transporta a lo alto, desde donde con la guía de San Pedro y dos ángeles contempla los sitios infernales; ve un lago rojo de metal derretido, y un río de pez ardiente «in cuius medio pons erat ferreus multam habens latitudinem per quem pontem iustorum anime tam facilius, tamque uelocius transeunt, quam immunes inueniuntur a delictis: peccatorum autem ponderibus grauati cum ad medium eius uenerint, tam efficitur subtilis, ut ad fili quantitatem eius latitudo uideatur redigi» (apud PATCH, El otro mundo, 120).

[8] Visio Tundali (siglo XII). El noble Tundalo, tras una agonía de tres días, recupera la salud y relata cómo su alma se separó del cuerpo durante ese lapso y viajó por las regiones de trasmundo bajo la guía de su ángel de la guarda; atraviesa un valle oscuro donde se queman las almas, una gran montaña que a un lado presenta fuego y al otro nieve y hielo («ex una parte illius montis erat ignis putidus, sulphureus et tenebrosus; ex altera parte nix glacialis»), y llega a un segundo valle muy profundo, fétido y sulfúreo, salvado por una larga tabla a modo de puente: «Post haec anima illa prae timore pedetentim angelum sequens venit ad vallem profundam, et putidam nimis, et tenebrosam; cujus profunditatem ipsa quidem anima videre non poterat; sonitum tamen sulphurei fluminis, et ululatum patientium in eo audiebat. Fumus vero de sulphure et de cadaveribus inde surgebat fetidus, qui superabat omnes poenas, quas prius viderat. Ibi erat tabula longissima, de uno monte in alium montem porrecta, in modum pontis supra vallem extensa: quae mille passus habebat in longitudine; in latitudine pedem unum. Quem pontem transire nemo nisi electus poterat. De hoc ponte vidit multos cadere». Más adelante Tundalo y el ángel ven un segundo puente, más largo y más estrecho, que cruza sobre un lago tempestuoso: «Euntes inde, longius viderunt stagnum amplum valde et tempestuosum, cujus fluctus elati non permittebant videre coelum. Ibi erat plurima multitudo bestiarum terribilium, mugientium ut animas devorarent. Per latum stagni pons multum angustus erat, et longus usque ad duo milliaria. Latitudo ejus erat unius palmi; longior erat et angustior, quam pons superior. Eratque tabula illa plena clavis ferreis acutissimis insertis; qui omnium transeuntium pedes perforabant. Omnesque bestiae ad illum pontem 
conveniebant, ut cibum inde sumerent; animas scilicet quae transire non poterant». Finalmente, llegan a un locus amoenus paradisíaco, cenido por un muro de plata refulgente ( viderunt murum nimis praeclarum. Erat enim argenteus totus, splendidus valde et decorus»), y poblado por hombres y mujeres vestidos de blanco que no cesan de alabar a la Trinidad con sus cantos: «Erant autem viri et feminae vestiti candidis vestimentis et pretiosissimis; sine macula et ruga, jucundi et hilares, gaudentesque, et sanctam Trinitatem laudantes. Candor autem vestimentorum, sicut nix recens erat, percussa solis radio» (HELINANDUS FRIGIDI MonTIS, Chronicon, PL, vol. CCXII, 1148, cols. 1041-1051) ${ }^{32}$.

[9] Purgatorio de San Patricio (siglo XII). Numerosas versiones, latinas y vernáculas, existen del relato del viaje del caballero Owen a la cueva de la isla del Purgatorio de San Patricio, en Irlanda. Citamos por la de Enrique de Saltrey, quien refiere cómo el caballero, tras atravesar diversas instancias dentro de la cueva, es arrojado por un viento junto a un río fétido y frío: «et ecce ventus turbinis ab aquilone veniebat, qui et ipsos daemones, et cum eis militem, totumque populum illum arripuit, et in quoddam flumen fetidum ac frigidissimum, in alium montis partem, flentes et miserabiliter ejulantes projecit; in quo inaestimabili frigore vexabantur.» Llega después a un segundo río, igualmente fétido, pero esta vez más ancho y no ya frío, sino de fuego, que explícitamente se dice ser el infierno; sobre él cruza un puente resbaladizo y estrecho, que sólo se ensancha al paso de los electos de Dios: «Trahentes igitur militem hostes novi cum tumultu magno et horrisono, pervenerunt ad flumen quoddam latissimum et fetidum, ac totum tanquam sulphurei incendii flamma coopertum, daemonumque multitudine repletum. Dixerunt ergo ei: Sub isto flumen noveris infernum esse. Pons vero protendebatur ultra flumen, in quo tria quasi impossibilia et transeuntibus valde formidanda videbantur, unum quod ita lubricus erat, ut etiamsi latus fuerit, nullus vel vix aliquis in eo pedem figere posset; alterum quod tam strictus et gracilis erat, ut nullus in eo stare vel ambulare valeret; tertium quod tam altus erat, et a flumine remotus ut horrendum esset deorsum aspicere.» Los demonios instan a Owen a que pase por el puente, y éste se ensancha a su paso, permiténdole acceder a la otra ribera: «Sed miles Christi fidelis, cogitans intra se, de quantis liberaverit eum malis advocatus suus piissimus Jesus, ipsius iterato nomine, pontem audacter ingressus, coepit pedetentim incedere, nihilque lubrici sub pedibus sentiens, firmus super pontem ambulabat in Domino confidens, et quo altius ascendit, eo spatiosiorem invenit pontem; et ecce post paululum tanta crevit pontis latitudo, ut publicae viae amplitudinem prae se ferret, et undecim carra sibi obviantia posset excipere. [...] Securus tandem procedens, et nihil sibi contrarium inveniens, vidit latitudinem pontis in tantum excrescere, et vix ex utraque parte ejus fines posset aspicere» (Henricus SAlteriensis, Tractatus de Purgatorio Sancti Patricii Hibernorum Apostoli, PL, vol. CLXXX, caps. VII-VIII, cols. 994-996).

[10] Visión de Thurkel (siglo XIII). Thurkel es llevado en visión por San Julián a la contemplación del infierno; ve un lago salado y frío, sobre el cual se tiende

${ }^{32}$ Existen varias versiones en distintas lenguas vernáculas de la Península Ibérica de la Visio Tundali (LEWIS, «The Vision of the Knight Túngano», 85-99), pero todas ellas son al parecer posteriores a Berceo. Del conocimiento que éste debió tener de la leyenda de Tundalo en su versión latina parece no haber dudas, si hemos de dar crédito a la tesis de John Walsh acerca de que la Visio Tundali constituye el principal modelo en el diseño que del Otro Mundo presenta el Poema de Santa Oria berceano (WALSH, «The Other World in Berceo's Vida de Santa Oria», 297 ss.). 
un puente lleno de aguijones y estacas agudísimas: «Deinde restabat pons magnus aculeis et sudibus per totum affixus quem pertransitare quemlibet oportebat antequam ad monte gaudii perveniret». Del otro lado del puente, quienes logran atravesarlo acceden al Paraíso (apud PATCH, El otro mundo, 129-130).

[11] Visión de Olav Asteson (siglo XIII). Refiere la balada noruega Draumkvaede que en sueños visitó Olav Asteson el trasmundo; accede al puente Gjallar: «tan alto en el aire, cubierto de oro rojo y adornado con pináculos dorados. Una serpiente, un perro y un toro había ahí, feroces y coléricos, para impedirle el paso. No obstante, Olav cruzó el puente y también vadeó un cenagoso pantano, donde jamás el pie encuentra apoyo. El puente, nos dice, estaba lleno de agudos ganchos en hilera, y el pantano hedía» (apud PATCH, El otro mundo, 130-132).

[12] Visión recogida por Étienne de Bourbon (siglo XIII). Cierto homo probus refiere a Étienne una visión experimentada por el padre de aquél, en la cual contempló un río ancho y fétido («litus cujusdam fluui et latissimi»), lleno de fuego, azufre, dragones, serpientes y otras bestias, y sobre el cual «uidit pontem artissimum et longissimum, qui uix uidebatur dimidii pedis latitudinis et pertingere uidebatur uersus celum. Cum autem, necessitate compulsus, pontem ascenderet et leuius magis ac magis ascenderet, et demones post eum, sed uix et cadendo, postquam uenit ad sumum, deficit ei pons»; al cabo del puente, el padre del hombre probo es recibido por la Virgen María» (apud PATCH, El otro mundo, 132-133).

[13] Le Chevalier de la Charrete de Chrétien de Troyes (siglo XII). Chrétien de Troyes relata célebremente cómo Lancelot atravesó el peligroso Puente de la Espada para acceder al castillo donde Ginebra estaba prisionera; primero describe el puente, consistente en una filosísima espada extendida entre ambas riberas, y el agua espesa, horrible y fría que corre debajo: «et voient l'eve felenesse,/ noire et bruiant, roide et espesse,/ tant leide et tant espoantable/ con se fust li fluns au deable,/ et tant perilleuse et parfonde/ qu'il n'est riens nule an tot le monde/ s'ele i cheoit, ne fust alee/ ausi com an la mer betee./ Et li ponz qui est an travers/ estoi de toz autres divers;/ qu'ainz tex ne fu ne ja mes n'iert./ Einz ne fu, qui voir m'an requiert,/ si max ponz ne si male planche:/ d'une espee forbie et blanche/ estoit li ponz sor l'eve froide;/ mes l'espee estoit forz et roide,/ et avoit deus lances de lonc.» Antes de cruzar Lancelot se desarma, y avanza por el puente aferrándose al cortante filo de la espada, de modo que hiere horriblemente sus desnudos pies y manos: «Bien s'iert sor l'espee tenuz,/ qui plus estoit tranchanz que fauz,/ as mains nues et si deschauz/ que il ne s'est lessiez an pié/ souler, ne chauce, n'avanpié./ De ce gueres ne s'esmaioit,/ s'es mains et es piez se plaioit;/ mialz se voloit il mahaignier/ que cheoir el pont et baignier/ an l'eve don ja mes n'issist./ A la grant dolor c'on li fist/ s'an passe outre et a grant destrece;/ mains et genols et piez se blece,/ mes tot le rasoage et sainne/ Amors qui le conduist et mainne,/ si li estoit a sofrir dolz./ A mains, a piez et a genolz/ fet tant que de l'autre part vient» (CHRÉTIEN DE TROYES, Le Chevalier de la Charrete, vv. 3009-3025; 3100-3117, pp. 92-95) ${ }^{33}$.

\footnotetext{
${ }^{33}$ Con leves variantes, y en general con evidente tendencia a la abbreviatio, repite la aventura el Lancelot de la Vulgata en prosa del siglo XIII (Lancelot, vol. II, cap. XXXVIII, 45-48, pp. 58-59). Tanto Chrétien como la Vulgata, por lo demás, relatan asimismo el fallido intento de Gauvain por cruzar otro peligroso puente, el Puente Sumergido o «Pont sos Eve», que se define casi como lo opuesto a la idea de un puente, dado que no pasa por sobre el agua para salvarla sino por entre medio de ella, a idéntica distancia de la
} 
Podemos a partir de la lectura de los textos precedentes extraer algunas conclusiones acerca de la morfología y funcionalidad de la imagen del río y el puente. En primer término, advertimos que la descripción del río es variable; en rigor, ni siquiera se trata siempre de un río, pues a veces puede ser una cañada (texto 6) o un valle (texto 8); en la mayoría de los casos en el río -o en sus analogables - hay fuego o algún elemento asimilable, como pez hirviente (textos $1,2,4,5,6,7,9,12$ ), y puede sumarse también un factor de pestilencia o fetidez (textos 3, 8); más raramente, el río es frío (textos 9, 10, 13), o se asimila a un pantano (textos 11, 13). Pero por sobre estas u otras diferencias accidentales, la casi totalidad de los ríos se presentan como lugar de castigo, ya se trate de un castigo de carácter definitivo, con lo cual el río adviene a la condición de infernal (textos 1, 2, 3, 4, 6, $7,9)$, ya se trate de un castigo transitorio o expiativo, con lo cual el río deviene purgatorial (textos 5, 8, 10); hay, con todo, tres excepciones: los textos 11 y 12 no especifican la condición infernal o purgatorial del río/ pantano, y el texto 13 consiste en una inmanentización de la aventura del viaje al trasmundo, por la cual el cruce del río por el puente peligroso connota otros valores referidos al esfuerzo caballeresco y a la prueba y finalmente al premio - el acceso a Ginebra- respectivamente exigida y prometido por el código del amor cortés. Sin embargo, y aun en estos casos, la asimilación del río con el castigo y las penas potenciales se conserva mediante alusión bastante clara. Otro rasgo que comparten la totalidad de los ríos y sus analogables es su condición unitaria; ninguno, en efecto, presenta el rasgo de la bifurcación en brazos que aparece en el poema de Berceo. Esto es así, pero se insinúa de todos modos en algunos textos la presencia del símbolo del binario complementario, no ciertamente mediante el rasgo concreto de la bifurcación del río en brazos, sino a través de otras imágenes connotativamente asimilables. En el texto 2 se mencionan cuatro ríos, dos de los cuales son, respectivamente, de leche, y por tanto blanco -como en Grimaldo- y de vino, y por tanto rojo — como en Berceo-, pero no se trata de una imagen binaria per se, sino de una manipulación a nuestros fines de una imagen cuaternaria a partir de la cual separamos dos ríos que se adaptan al modelo que perseguimos. En el texto 8 existen asimismo cualificaciones cromáticas en relación binaria asimilables a las de Berceo, pues se habla de una montaña que a un lado tiene fuego - rojo- y al otro lado nieve y hielo — blanco-, y algo similar ocurre en el texto 9, donde se presentan dos ríos, ambos fétidos, pero uno frío y por tanto blanco, y otro de fuego y por tanto rojo. Por último, los textos 11 y 13 hablan, en relación con lo que pasa por debajo de los puentes, o bien de un pantano (texto 11), o bien de un agua espesa y dura, esto es, barrosa (texto 13); el agua

superficie y del lecho del río, obligando a quien intente su paso a correr el riesgo de ahogarse ( $c f r$. CHRÉTIEN DE TROYES, Le Chevalier de la Charrete, vv. 653-667; 50965128, pp. 21; 155-156; Lancelot, vol. II, cap. XXXVI, 39-40, p. 19). 
barrosa y pantanosa es de suyo una mezcla de dos principios complementarios, el agua y la tierra, el líquido y el sólido, por donde la imagen binaria vendría a hacerse presente. Pero el caso es que ninguna de estas imágenes vale como modelo directo para la del río bifurcado del sueño de Domingo, por dos razones: en primer término, porque en varios de estos textos el binario no radica en el río que es objeto del pasaje y de la prueba peligrosa, sino en imágenes adyacentes como la montaña u otros ríos previos; en segundo término, porque los dos únicos casos donde el binario sí radica exclusivamente en el río objeto del pasaje, aquél se presenta bajo la forma integrada y en cierto modo diluida del barro y el lodo, por donde más que de un binario estricto estaríamos hablando de una superación del binario en una nueva unidad. Adviértase, por lo demás, que con la excepción del ejemplo de Chrétien de Troyes todos los textos aluden a un río que marca, real o simbólicamente, una frontera entre la vida inmanente y la vida ultraterrena; el paso de ese límite conlleva de suyo una indefinición acerca del resultado, una alternativa de bien y salvación o de mal y condena, pero esa alternativa no radica de suyo en el río, en el límite mismo, sino en el puente que lo atraviesa y que vehiculiza la prueba mediante la cual el hombre debe definir su destino: la opción por el cielo o el infierno, en consecuencia, está dada por el éxito o el fracaso en la travesía del puente, y no radica plásticamente en la forma del río o límite atravesado por dicho puente. La notable innovación de Grimaldo y Berceo ha de consistir, pues, en la extensión plástica de dicha opción del puente al río, mediante la introducción en éste de la imagen binaria de los dos brazos.

Pasemos al puente. En todos los textos el puente se define como riesgoso, como cargado de peligro para quien lo atraviesa; este peligro se deriva o bien de su estrechez (textos 1, 4, 5, 6, 7, 8, 9, 12, 13), que en algunos casos desaparece cuando quien cruza es un justo, o bien de su fragilidad (textos 1, 9), o bien del hecho de que hiere mediante un filo cortante, estacas, agujas, puntas de hierro o ganchos (textos 8, 10, 11, 13), o bien de alguna virtud inespecífica que hace que los pecadores caigan al fuego del río (textos 2, 3) ${ }^{34}$. En algunos casos contribuye al riesgo que conlleva el paso del puente su gran altura (texto 6) o inclusive una condición de verticalidad (textos 11,12 ) por la cual el puente se eleva hacia lo alto mediante una virtual identificación del adelante de la otra ribera con el arriba del cielo, con lo que la imagen misma del puente acaba asimilándose a las de otros símbolos axiales cuya función tradicional es la de vincular los diferentes planos de la existencia —inmanencia y trascendencia; manifestación y principio; lo profano y lo sagrado; infierno, tierra y cielo-, como el árbol, la columna, la escala o la montaña ${ }^{35}$. De todos estos rasgos, Grimaldo

\footnotetext{
${ }^{34}$ En el caso del Puente Sumergido, que no analizamos pero citamos en la nota 33, el peligro y el riesgo radican en el agua misma que cubre al puente.

35 «Los dos mundos representados por las dos orillas son, en el sentido más general, el cielo y la tierra, que al comienzo estaban unidos y fueron separados por el hecho mis-
} 
y Berceo conservan el de la estrechez, omiten el de la verticalidad y el de la condición hiriente del puente, y acentúan mediante remarcado énfasis el de la fragilidad, al señalar como materia del puente una tan débil y riesgosa de quiebre o desintegración como el vidrio. Se trata, eso sí, de una fragilidad ambigua, que conlleva a la vez peyoración y ponderación, pues si el vidrio connota por una parte el peligro propio de su endeblez y debilidad, por otra parte su condición transparente alude a inequívocos valores de luz, pureza y conocimiento intelectual, vale decir, aquellos méritos que garantizan el éxito en la empresa de su pasaje y ganan para quien la acomete el premio de la otra ribera, esto es, del paraíso mismo.

Debemos ahora, una vez establecidos los ragos definitorios de la imagen del río y el puente en la tradición de las visiones y las aventuras maravillosas medievales, detenernos en el análisis particular de la solución de Grimaldo y de Berceo. Queda dicho que el río, según los casos, se identifica en la tradición medieval, por sobre su valor básico de lugar de castigo y dolor, con el infierno o con el purgatorio; hay, con todo, un valor simbólico más global y universal que, desde Heráclito hasta nuestros días, define al río como la imagen característica del flujo vital-temporal (CHEVALIER, Diccionario, 885-886; CiRlot, Diccionario, 389). El acto simbólico de cruzar el río implica, por tanto, la superación del estado contingente propio de la vida humana y el acceso a un estado superior de vida perdurable ${ }^{36}$; es este valor, sobre todo, el que cargan el río y su cruce en la solución de Grimaldo y Berceo, y es en relación con este valor, más que con el previamente explicado de sitio infernal o purgatorial de castigo, que ha de ser posible desentrañar el sentido de los brazos en que se bifurca el río y de las imágenes numérica y cromática concomitantes. En cuanto al puente, es éste el lugar para aducir su etimología en auxilio de su simbolismo; el valor connotativo de riesgo y

mo de la manifestación, cuyo dominio íntegro se asimila entonces a un río o a un mar que se extiende entre ellos. El puente equivale exactamente, pues, al pilar que une el cielo y la tierra a la vez que los mantiene separados; y a causa de esta significación, debe ser concebido esencialmente como vertical, lo mismo que todos los demás símbolos del 'Eje del Mundo' [...]. Así, el paso del puente no es, en definitiva, sino el recorrido del eje, único medio de unión mutua de los diferentes estados» (GUÉNON, «El simbolismo del puente», 337-338; cfr. CHEVAlIER, Diccionario, 853; CIRLOT, Diccionario, 375-376; SUÁREZ PALLASÁ, «Sobre algunos aspectos», 111-112).

${ }^{36}$ Según Guénon, la superación de la contingencia de la vida simbolizada por el río puede realizarse mediante tres gestos simbólicos: a) remontando las aguas del río contra corriente hasta sus fuentes, identificadas con el Principio Metafísico, b) navegando el río corriente abajo hasta desembocar en en mar, imagen también del Principio y de los orígenes primordiales; c) cruzando el río de una ribera a otra, sea mediante el tránsito por un puente como ocurre en nuestros ejemplos, sea mediante un vado de las aguas mismas; en esta tercera posibilidad la ribera citerior queda identificada con el mundo o estado fenoménico de la contingencia y la inmanencia - y en tal sentido ocurre una asimilación semántica de hecho entre la ribera y el río mismo-, en tanto la ribera ulterior se identifica con el mundo o estado de lo trascendente (GUÉNON, «El paso de las aguas», 300-302). 
peligro ha quedado debidamente establecido a partir de los rasgos de estrechez, fragilidad y condición hiriente que presentan todos los puentes analizados, pero estos rasgos no son otra cosa que expansiones plásticas o ilustraciones de una semántica más básica que la palabra puente carga, a través del latín pons-pontis, desde su misma raíz indoeuropea pent-, a la que suele atribuirse un vago valor de 'andar' o 'pisar', o bien de 'camino' (ROBERTSPASTOR, Diccionario, 128), pero que a poco de tomarse en cuenta sus derivados en diversas lenguas debe enriquecerse con otros valores. En efecto, de la misma raíz indoeuropea pent- derivan, además del latín pons-pontis 'puente', el griego póntos 'mar' y el sánscrito pantáh 'camino'. ¿Qué pueden tener en común un camino, un puente y el mar en cuanto derivados de una misma raíz? Investigaciones del lingüista francés Émile Benveniste y el filólogo hispano-argentino Aquilino Suárez Pallasá han determinado que, dados sus derivados, la raíz pent- debió tener un significado más preciso de 'camino o lugar de tránsito peligroso', 'franqueamiento o paso por un sitio hostil o desconocido', de donde cada una de las lenguas históricas posteriores definió sus palabras por especificación de este concepto según sus respectivas circunstancias geográficas; así, para los antiguos arios invasores de la India, gentes mediteráneas, el tránsito peligroso se realizaba a través de extensas tierras continentales pobladas de enemigos, esto es, el sitio peligroso era de suyo un 'camino' terrestre: pantáh; por el contrario, para los griegos, pobladores de islas y penínsulas vinculadas entre sí por vía marítima, el lugar de tránsito y de peligro era eminentemente acuático, el 'mar': póntos; en cuanto a los latinos de los primeros tiempos, recién instalados junto al Tíber, el tránsito cargado de peligro era precisamente este río que los separaba de las tierras de los hostiles etruscos, y que debía atravesarse mediante un 'puente': pons-pontis (cfr. BENVENISTE, Problèmes, 289-307; SuÁreZ PALlasá, «Sobre algunos aspectos», 101-114.) Añádase que a la misma raíz indoeuropea pent- se remiten el antiguo alemán pfad y el anglosajón findan, étimos respectivos del alemán finden y el inglés to find, ambos 'encontrar', que aluden indirectamente, también ellos, a las circunstancias azarosas o desconocidas que pueden salir al paso de quien realiza el tránsito o el camino peligroso. Bien sabemos que la lengua poética y literaria se define entre otras cosas por su capacidad de trascender la simple función comunicativa y denotativa y por operar en un plano superior de referencialidad simbólica; es por ello que la lengua poética de los textos analizados ha sabido rescatar los valores semánticos originales de la palabra puente, en consonancia, por lo demás, con el significado arquetípico que el objeto puente ha tenido tradicionalmente en diversas culturas en relación con el simbolismo de pasaje o tránsito de un estado u otro - de la tierra al cielo, del mundo sensible al suprasensible, de la mortalidad a la inmortalidad, etc.-; así, y más allá de especificaciones de detalle que las distintas tradiciones doctrinales, religiosas o culturales han establecido para el objeto, el puente ha consistido siem- 
pre en un símbolo iniciático connotativo de la elevación a un estado superior y trascendente a partir de uno inferior e inmanente. Interprétese en relación con esto, también, el término castellano pontífice, cuyo étimo latino, pontifex, significa literalmente 'hacedor de puentes', por cuanto el sumo sacerdote era quien tendía en la antigua Roma el puente ritual entre el mundo de los hombres y el mundo de los dioses (CHEVAlIER, Diccionario, 853854; CiRlot, Diccionario, 375-376; GuÉNON, «El paso de las aguas», 336339; SuÁREZ PALlASÁ, «Sobre algunos aspectos», 101-114). Dado lo arduo y riesgoso de todo rito iniciático, el puente que lo simboliza adopta a menudo la forma ya de una construcción frágil, siempre pronta a quebrarse o romperse a causa de su material - vidrio, por caso-, ya de una construcción estrecha que exige un imposible equilibrio, ya de una construcción filosa que exige de quien la atraviesa, a causa de la estrechez y endeblez, aferrarse a sus bordes hirientes y lastimarse con ellos. Paso de un estado inferior a otro superior, lo cual equivale, en el plano ritual, a iniciación, mediante un acto o gesto que necesariamente conlleva riesgo y peligro: tal el sentido simbólico del cruce del río por el puente en Grimaldo, en Berceo, y en los demás textos vistos. Nos resta todavía, empero, para completar nuestros análisis, interpretar debidamente las tres imágenes accidentales o secundarias que se predican de la imagen sustancial del río y el puente en el sueño de Domingo según Berceo, y que refieren la materia del puente - vidrio-, la cantidad del río a partir de su bifurcación en dos brazos - binario-, y la cualidad cromática de esos dos brazos en relación asimismo con la materia de dos términos de comparación —blanco como el cristal, rojo como el vino-.

\section{CANTIDAD, CUALIDAD, MATERIA}

La bifurcación del río evoca, desde la perspectiva del simbolismo numérico, la escisión primera y fundamental de la unidad original y la generación de la multiplicidad, vale decir, el surgimiento de la manifestación, del mundo contingente, a partir del Principio. En efecto, el binario, en cuanto primera cantidad múltiple o plural, simboliza la idea misma de multiplicidad en su aspecto más radical, y en consecuencia a menudo se carga de connotaciones negativas que, a partir siempre de su valor básico de escisión del ser, lo convierten en representación del mal, la discordia, la lucha, el conflicto; se trata en estos casos del denominado dos contradictorio, vale decir, del binario que entraña oposición insoluble mediante síntesis o armonización; por el contrario, cuando la síntesis es posible, ocurre el llamado dos complementario (CAPELlA, De Nuptiis, VII, 368; S. ISIDORI Liber numerorum, II, 181; H. DE S. VICTORE Exegetica I, 22-23; GONZÁLEZ, «El número como símbolo», 89118; HOPPER, Medieval Number Symbolism, passim; BUTLER, Number Symbolism, 22-46; CheVAlier, Diccionario, 426-428; CIRLOT, Diccionario, 329, 100-101). Pero lo que importa retener es el valor fundante de escisión básica 
del ser, de primera y más radical pluralidad; siendo que la pluralidad es definitoria del devenir y de la contingencia, se entiende ahora por qué afirmábamos más arriba que el valor que corresponde al río de Grimaldo y Berceo, más aun que el de sitio de castigo infernal o purgatorial, es el de vida o tiempo fluyentes: al incluir en su diseño formal, como componente destacado, al binario de la escisión del ser y la multiplicidad, el río se configura como imagen acabada del fluir temporal-vital signado por ese cambio y esa transformación incesantes que se derivan, precisamente, de la contingencia que imponen la división y la pluralidad. Con todo, la vida contingente guarda respecto de la Vida anterior, eterna y una que le ha dado origen una relación de dependencia ontológica que le asegura el necesario regreso al seno de la unidad y el ser pleno; ello ocurre, en el plano del simbolismo numérico tradicional, en el ternario. El ternario es, en cuanto número perfecto, no sólo la expresión de la vida íntima de la unidad, sino la resolución de la división y el conflicto propios de la dualidad en un regreso a la unidad primera, que es así alfa y omega de todo proceso de manifestación ${ }^{37}$; la pluralidad y la escisión del ser resultan por tanto transitorios, no definitivos, y es a este propósito que en la entera construcción del sueño los números dos y tres establecen una relación casi simbiótica: en efecto, el río presenta dos brazos, pero sumada a éstos, operante y sin desaparecer, persiste la «madre primera» (231a) de donde han surgido y que los mantiene en cierto modo unidos y contenidos, en un juego matemático de $1+2=3$; una vez atravesado el río, vale decir, una vez superada la escisión de la pluralidad binaria, en la otra ribera espera a Domingo el premio celestial de las tres coronas, según una evidente superación del binario terreno en el ternario celestial ([2 brazos de río = vida terrena $]>[3$ coronas $=$ vida eterna $]$ ) , por último, más que significativo resulta el hecho de que, a manera de transición o puente — nunca más adecuada la metáfora que en relación con este texto- entre la tierra binaria y el cielo ternario, las tres coronas que simbolizan la gloria celestial sean portadas y ofrecidas al santo por dos hombres de blanco, que por su cantidad remiten a la tierra y por el color de sus ropas — según ahondaremos después- al cielo; a partir de esta misma relación entre las tres coronas y los dos portadores es que puede explicarse, según conjeturamos más arriba, la sustitución del septenario de Grimaldo por el senario de Berceo a propósito de la cantidad de veces más hermosa y fulgente que resulta la tercera corona $(6=2 \times 3)$.

Es precisamente en relación con el carácter no definitivo de la escisión representada por el binario de los brazos del río que debemos interpretar la

\footnotetext{
37 Clarísimamente expone San Isidoro de Sevilla la identificación del tres con el uno en cuanto vida íntima de aquél o regreso a aquél: «Tres unum sunt» (Liber numerorum, IV, 181; cfr. CAPELlA, De Nuptiis, VII, 363-421; H. DE S. VICTORE Exegetica I, 22; GONZÁLEZ, «El número como símbolo», 89-118; «La espada rota», 73-81; HoPPER, Medieval Number Symbolism, passim; BUTLER, Number Symbolism, 22-46; GUÉNON, La gran tríada, passim; Chevalier, Diccionario, 1016-1020; CIRlot, Diccionario, 328-333, 433-435).
} 
cualidad cromática de éstos. En cuanto simbolización de la vida misma en su fluir, su contingencia y su transitoriedad, los dos brazos expresan las innumerables alternativas y constantes opciones que definen el acto mismo de vivir; en tal sentido, los colores rojo y blanco subrayan esta misma significación mediante la formulación cromática arquetípica de un par de opuestos complementarios que sintetizan la idea misma de alternativa según la dinámica de la libre elección humana. Los polos de la elección no siempre son moralmente equivalentes o incluso igualmente válidos, pero aun en estos casos los reputamos como opuestos complementarios, y no contradictorios, dado que coexisten, sucesiva o simultáneamente, a lo largo de la vida humana. Es dable en consecuencia distinguir dos realizaciones del binario blanco y rojo, una como par de opuestos complementarios equivalentes y simbolizantes de aspectos igualmente válidos de la vida, y otra como par de opuestos complementarios no equivalentes pero siempre coexistentes y por ello no contradictorios; a la primera realización se adscriben significados tales como rojo = vida activa, lo afectivo, la guerra, la caridad y el amor divino y humano $v$ s. blanco $=$ vida contemplativa, lo cognoscitivo, la paz, la fe y el conocimiento divino y humano; a la segunda realización se adscriben significados tales como rojo $=$ pecado, odio, ira o crueldad $v$ s. blanco $=$ gracia, bondad, humildad o inocencia (PORTAL, El simbolismo de los colores, 1329, 47-69; CHEVAliER, Diccionario, 189-193, 888-890; CIRLOT, Diccionario, $101-102,135-141)^{38}$. A lo largo de una vida humana en su fluir y en su libre progresión, tanto los primeros cuanto los segundos pares coexisten y se complementan por sobre la condición moralmente equivalente o no equivalente de unos u otros; existe, con todo, un valor que comparten plenamente el rojo y el blanco más allá de las antedichas contraposiciones, y por el cual su simbolismo ya no se complementa sino se identifica sinonímicamente: el del paso de un estado inferior a otro superior, lo cual equivale a decir, en un plano fáctico, a la muerte y la resurrección, en un plano ritual, a la iniciación, y en un plano espiritual, a la iluminación mística (PORTAL, El simbolismo de los colores, 22-29, 60; CHEVALIER, Diccionario, 189-193, 888-890). En conclusión, cabe establecer sobre la base de estos tres tipos de valores simbólicos discernibles en el blanco y el rojo de los brazos del río tres

${ }^{38}$ Las connotaciones negativas que adquiere el rojo en el segundo grupo de oposiciones binarias quedan convenientemente subrayadas por Berceo cuando adopta el término vermejo, que no utilizaba Grimaldo, quien apenas aludía al color mediante la perífrasis «ad similitudem sanguinis sanguineum»; el color bermejo o rojo terroso implica una tonalidad oscura que cromática y simbólicamente lo coloca como intermedio entre el rojo puro y el negro o el ocre, razón por la cual algunos de los valores negativos de éstos se trasladan a él: «[...] en lugar de representar el fuego límpido del amor celeste (el rojo), caracteriza al fuego impuro que arde bajo la tierra, el fuego del infierno: es un color ctónico» (Chevalier, Diccionario, 186). El valor ctónico o infernal del bermejo nos remite nuevamente, por lo tanto, a la identificación del río con el lugar de las penas de ultratumba. 
correspondientes significados para éstos y para el cruce del río por el puente: a) los valores coincidentes del blanco y el rojo identifican sinonímicamente a ambos colores, en cuanto símbolos, con el ya analizado valor del cruce del río por el puente como imagen del paso de un estado inferior a otro superior, de la tierra al cielo o de lo contingente a lo absoluto; b) los valores equivalentes del blanco y el rojo identifican descriptivamente a ambos colores, en cuanto símbolos, con el valor del río como imagen de la vida terrena en su fluir temporal y en su progresión en base a alternativas libremente elegidas por el hombre, siendo que cualquiera de las dos opciones contenidas en el binario complementario tiene idéntica validez en cuanto vía o instrumento para la ganancia, a partir de la vida terrena simbolizada por el río, de la vida eterna simbolizada por el más allá del río; c) los valores no equivalentes del blanco y el rojo identifican jerárquicamente a ambos colores, en cuanto símbolos, con los aspectos válidos —el blanco-e inválidos - el rojo - de la vida terrena en orden a la ganancia de la vida eterna, siendo que en este caso las dos opciones contenidas en el binario complementario, bien que coexistentes a lo largo del curso vital, no valen idéntica ni indistintamente como medios para el acceso a la trascendencia. Esta compleja estructura semántica, como se ve, combina y potencia recíprocamente los valores correspondientes al binario y al cromatismo en cuanto accidentes de la sustancia-río, y define la característica polisemia propia del discurso simbólico. Se explica así, finalmente, el porqué de la bifurcación del río en dos brazos de colores opuestos: el río-vida conlleva la necesidad de una opción axiológica recurrente o renovada entre dos vías o medios de acceso al más allá de la vida, opción de la cual dependen el éxito o el fracaso de dicho acceso y que contempla, sobre la base semántica del acceso mismo al cual se aspira - el blanco y el rojo como símbolos sinonímicos del paso de la tierra al cielo- las posibilidades de una elección entre dos caminos igualmente válidos pero más o menos aptos según los casos —el blanco como símbolo de la vida contemplativa, la fe y el conocimiento frente al rojo como símbolo de la vida activa, la caridad y la afectividad-, y de una elección entre un camino válido y otro inválido, pero ambos presentes en simultaneidad durante la vida —el blanco como símbolo de la gracia, la bondad y la humildad frente al rojo como símbolo del pecado, el odio y la ira-.

Lo cual nos lleva, por fin, a la elucidación del tercer y último símbolo accidental del complejo: la materia indirectamente aludida mediante la comparación del blanco y el rojo de los brazos del río con, respectivamente, la leche y la sangre —en Grimaldo- y el cristal y el vino - en Berceo-. Es precisamente esta segunda modificación de la fuente latina, que convierte a la sangre en vino, la que resulta a un tiempo más fácil de explicar y más difícil de comprender en su provecho funcional dentro del símbolo, dado que en un contexto cultural cristiano sangre y vino se identifican como un mismo símbolo a partir de la transustanciación eucarística. Básicamente, 
sangre y vino en plena identificación simbólica connotan según los contextos valores positivos o negativos; los primeros, inequívocamente relacionados con la dimensión eucarística de ambas imágenes, refieren las ideas de vida e inmortalidad; los segundos aluden al desborde sensorial o corporal, lo pasional, la embriaguez, la cólera (CHEVALIER, Diccionario, 909-910, 1072-1074). Pero aun admitiendo la ambivalencia de ambas imágenes en cuanto a su valoración positiva o negativa, es la imagen del vino aquella que acentúa más y mejor las connotaciones negativas del símbolo cromático rojo y desacentúa las positivas, y muy especialmente en un contexto bíblico-cristiano, según el cual el vino se erige en signo del extravío humano y de los condignos cólera y castigo divinos, tal como se expresa en los libros proféticos del AT (Isaías, Jeremías) y del NT (Apocalipsis) ${ }^{39}$. Existe por tanto en la solución berceana frente al hipotexto de Grimaldo una efectiva intensificación de la valoración negativa del símbolo cromático rojo a partir de la sustitución de la sangre por el vino como materia de comparación y de la elección del lexema vermejo con su connotación de oscuridad; si a ello sumamos la otra sustitución de materia de comparación operada por Berceo - el cristal en lugar de la leche en relación con el blanco-, estaremos por fin en condiciones de definir la clave de la innovación semántica de la imagen llevada a cabo por el poeta. La leche mencionada por Grimaldo opera simbólicamente como el alimento espiritual y su directa consecuencia, la inmortalidad, pero también como el conocimiento o la contemplación de Dios (CHEvalier, Diccionario, 631-633); es este tercer significado el elemento en común que posibilita su reemplazo por la piedra cristal en la versión de Berceo, dado que el cristal enfatiza aún más este valor cognoscitivo, reforzándolo mediante las ideas conexas de lucidez o claridad de mente y pureza de pensamiento (CHEVAliER, Diccionario, 358-360). Se trata de valores que ya residían genéricamente en la semántica del blanco en cuanto símbolo cromático de la vida contemplativa, la iluminación mística y la fe, y que la especificación material de ese color como leche o cristal no hace sino ratificar y subrayar; pero la materia-cristal añade a estos valores genéricos una importante connotación derivada de su carácter transparente, que permite a

39 «Elevare, elevare, consurge, Ierusalem, quae bibisti de manu Domini calicem irae eius; usque ad fundum calicis soporis bibisti, et potasti usque ad faeces» (Is. 51, 17). «Quia sic dicit Dominus exercituum, Deus Israel: Sume calicem vini furoris huius de manu mea, et propinabis de illo cunctis gentibus, ad quas ego mittam te. Et bibent, et turbabuntur et insanient a facie gladii quem ego mittam inter eos. Et accepi calicem de manu Domini, et propinavi cunctis gentibus ad quas misit me Dominus: Ierusalem, et civitatibus Iuda, et regibus eius, et principibus eius, ut darem eos in solitudinem, et in stuporem, et in sibilum, et in maledictionem, sicut est dies ista [...]. Et dices ad eos: Haec dicit Dominus exercituum, Deus Israel: Bibite, et inebriamini, et vomite; et cadite, neque surgatis a facie gladii quem ego mittam inter vos» (Ier. 25, 15-18, 27). «Et de ore eius procedit gladius ex utraque parte acutus: ut in ipso percutiat gentes. Et ipse reget eas in virga ferrea: et ipse calcat torcular vini furoris irae Dei omnipotentis» (Ap. 19, 15).

RLit, 2007, julio-diciembre, vol. LXIX, n. ${ }^{\circ}$ 138, 411-447, ISSN: 0034-849 
la luz manifestarse en plenitud y con todo brillo a su través — no en vano la misma palabra blanco remite, a través de su étimo indoeuropeo, a las raíces bhel-/blank-, 'brillar', 'brillante' (ROBERTS-PASTOR, Diccionario etimológico, 23-24)—, y que posibilita asimismo a todos los colores hacerse presentes en el mismo blanco-luz en cuanto suma de la totalidad del espectro cromático. De este modo, puede decirse que el blanco, al abandonar materialmente su condición de blanco-pigmento propia de una materia como la leche y constituirse como blanco-luz en el cristal, deja de ser un color para ser todos los colores reunidos e integrados, y al serlo pasa a incluir en su seno al mismo rojo que independientemente se le oponía; si en lo que tienen de opuestos complementarios no equivalentes - pecado/gracia, odio/bondad, ira/humildad - el rojo y el blanco excluyen toda posibilidad de síntesis e integración, en lo que tienen de opuestos complementarios equivalentes - activo/contemplativo, afectivo/cognoscitivo, caridad/fe- el rojo y el blanco se sintetizan e integran en esta superior realización no pigmentaria sino lumínica del blanco como no-color y suma de todos los colores, vale decir, como unión y neutralización de contrarios no excluyentes (CHEVALIER, Diccionario, 358). La jerarquización del binario rojo/blanco en cuanto vías de acceso a la vida eterna a partir de la terrena se fortalece aún más, por lo tanto, en favor del segundo término, pues éste no solamente aparece connotado como mejor en el plano de los opuestos complementarios equivalentes - aunque igualmente válidas, la contemplación es más adecuada que la acción para llegar a Dios en el caso de un monje- y como únicamente apto frente al rojo no apto en el caso de los opuestos complementarios no equivalentes - la gracia frente al pecado-, sino que se muestra ahora como síntesis de los valores complementarios equivalentes del rojo y del blanco en cuanto pigmento en una superior realización de la blancura como luz y transparencia en el cristal de su nueva materia. Berceo ha enfatizado, entonces, la jerarquía del blanco respecto del rojo de una manera doble: en primer término por la especificación del vago rojo sanguineum de Grimaldo como vermejo, esto es, como rojo terroso, oscuro, sombrío, y por ello connotado oblicuamente como negativo; en segundo término por la transformación del blanco-pigmento en blanco-luz gracias a su materialización como cristal transparente, lo cual conlleva una recategorización del blanco no ya como color sino como suma de todos los colores, de donde se configura como pertinentísima imagen de la coincidencia de opuestos y la totalidad de virtualidades de la vida humana.

Y será por añadidura esta misma materia, el cristal, que ha sido causa de la mayor jerarquía del blanco respecto del rojo en cuanto vía de acceso a la meta eterna, el elemento simbólico accidental que permitirá una sugerente identificación entre el río y el puente, pues éste está hecho asimismo de vidrio, materia asimilable al cristal en su sustancia básica. El cristal/vidrio identifica, pues, el río con el puente, el punto de partida - la vida 
terrena- con el medio o instrumento que se ofrece para trascenderla -el puente-; dicho de otro modo: es la vida terrena misma —el río bajo su aspecto de blanco/cristal = suma de las posibilidades humanas-la que contiene en su propia virtualidad y potencialidad el instrumento que más adecuadamente permite trascenderla —el puente de vidrio/cristal-y coronarla dándole un sentido. En términos de interpretación alegórico-moral, según estipula el cuarto de los sentidos del esquema medieval, cabría afirmar que la imagen del río y del puente, materialmente identificadas a través del cristal/vidrio que las constituye, significan la conducta virtuosa, tanto en lo intelectual - contemplación, fe, iluminación mística- cuanto en lo moral — gracia, bondad, humildad, pureza, paz-, que se destaca como opción privilegiada dentro del conjunto de virtualidades de la vida terrena —el brazo blanco como cristal dentro del río- y que por ello mismo se erige en camino, medio o instrumento para trascender la vida terrena - el puente de vidrio- y ganar la eterna. Así se postula y se funda, sobre la base compartida de la materia-cristal/vidrio que significa la virtud en su más comprensiva dimensión, una continuidad entre la inmanencia y la trascendencia, la vida terrena y la celestial, el acá y el Allá, pues el blanco no solamente opera como simbólico factor de unión entre la vida humana de este mundo y el puente o paso que permite trascenderla, sino también como vínculo directo entre esta vida y la otra, la tierra y el cielo, por cuanto los dos hombres que portan las coronas y las ofrecen a Domingo a modo se alegórico premio eterno visten también ellos «con almátigas blancas de finos ciclatones» (232a). Es, en consecuencia, el elemento cromático blanco la constante simbólica que vincula y constituye como un continuum ontológico y axiológico a las tres etapas de la vida de los hombres, que son además los tres núcleos que definen la narración onírica del texto: a) vida terrena = río con un brazo blanco como el cristal, b) tránsito arduo entre la vida terrena y la vida eterna $=$ puente de vidrio/cristal, c) vida eterna $=$ dos hombres vestidos de blanco. El punto de partida, el medio o instrumento y la meta son inescindibles en su entidad y su valor, porque no sólo la vida eterna comienza en la vida terrena y el Reino de Dios ya ha dado inicio ${ }^{40}$, sino que la misma vida terrena es, además de punto de partida, camino o herramienta de su propia superación; el blanco y el cristal/vidrio vienen a decir entonces magníficamente, en la plástica configuración de la alegoría berceana, que lo que somos en esta vida seremos en la próxima, y que no hay rupturas ni brusquedades en el paso del aquí al Allá. El sueño de Santo Domingo de Silos en

40 «Porro si in digito Dei eiicio daemonia: profecto pervenit in vos regnum Dei» (Lc. 11, 20). «Si autem ego in Spiritu Dei eiicio daemones, igitur pervenit in vos regnum Dei» (Mt. 12, 28). «Et dicebat: Sic est regnum Dei, quemadmodum si homo iaciat sementem in terram, et dormiat, et exsurgat nocte et die, et semen germinet, et increscat dum nescit ille. Ultro enim terra fructificat, primum herbam, deinde spicam, deinde plenum frumentum in spica» $(M c .4,26-28)$. 
la versión de Berceo ofrece un sintético tratado de escatología alegórica que complejiza y enriquece profundamente la semántica de su fuente directa mediante estratégicas modificaciones de símbolos accidentales — sangre >vino, leche $>$ cristal, identificación material río $=$ puente - , los cuales, aunque leves en el plano fenoménico y formal de la alegoría, demuestran ser radicales en el plano funcional y en la definición del sentido último del texto.

\section{BIBLIOGRAFÍA CITADA}

ACEBRÓN RUIZ, Julián, Sueño y ensueños en la literatura castellana medieval y del siglo XVI, Cáceres, Universidad de Extremadura, 2004.

S. Agustín, La ciudad de Dios, en sus Obras, $2^{\mathrm{a}}$ ed., Edición preparada por José Morán OSA (edición bilingüe latín-español), Madrid, BAC, 1965.

ARTILES, Joaquín, Los recursos literarios de Berceo, $2^{\text {a }}$ ed., Madrid, Gredos, 1968.

AUERBACH, Erich, Figura, Madrid, Trotta, 1998.

BALESTRINI, María Cristina, «Si cosa de Dios eres...: El discurso de lo sobrenatural en la Vida de Santo Domingo de Silos», en El hispanismo al final del milenio. Actas del Quinto Congreso Argentino de Hispanistas, Córdoba, Asociación Argentina de Hispanistas - Universidad Nacional de Córdoba, 1998, vol. I, pp. 151-160.

BaÑos VALleJo, Fernando, «Lo sobrenatural en la Vida de Santo Domingo», Berceo, 1986, 110-111, 21-32.

Benveniste, Émile, Problèmes de Linguistique Générale, Paris, Gallimard, 1966.

BERCEO, Gonzalo de, Obra completa, Editores varios, Coordinado por Isabel Uría, Madrid, Espasa Calpe, 1992.

Biblia Sacra iuxta Vulgatam Clementinam, Nova editio logicis partitionibus aliisque subsidiis ornata a Alberto Colunga et Laurentio Turrado, Sexta editio, Matriti, BAC, 1982.

Bonifacius Moguntinus, Epistulae, en Migne, J. P. (ed.), Patrologia Latina Database, s.1., Chadwyck-Healey INC., s.d., vol. LXXXIX, cols. 713-720.

BUTLER, Christopher, Number Symbolism, London, Routledge and Kegan Paul, 1970.

M.M.F. CAPELla, De Nuptiis Philologiae et Mercurii Libri VIIII, Edidit Adolfus Dick, Addenda et corrigenda iterum adiecit Jean Préaux, Stutgardiae, in Aedibus B.G. Teubneri, 1978.

A Celtic Miscellany, Translations from the Celtic Literatures by Kenneth Hurlstone Jackson, Middlesex, Penguin Classics, 1971.

ChEvalier, Jean (dir.), Diccionario de los símbolos, Barcelona, Herder, 1986.

ChrétIEN DE TROYes, Le chevalier de la charrete, Publié par Mario Roques, Paris, Honoré Champion, 1983.

CIRLOT, Juan Eduardo, Diccionario de símbolos, 6a ed., Barcelona, Labor, 1985.

CVITANovic, Dinko, De Berceo a Borges. La alegoría en las letras hispánicas, Buenos Aires, Fernando García Cambeiro, 1995.

DE BRUYNE, Edgar, Estudios de estética medieval, Madrid, Gredos, 1959, 3 vols

DEVINE, Arthur, «Prophecy», en The Catholic Encyclopaedia, New York, The Universal Knowledge Foundation INC., 1913, vol. 12, pp. 473-477.

DutTON, Brian (ed.), BERCEO, Gonzalo de, Obras completas IV: La vida de Santo Domingo de Silos, London, Tamesis Books, 1978.

ECO, Umberto, Arte y belleza en la estética medieval, Barcelona, Lumen, 1997.

ELIADE, Mircea, Imágenes y símbolos, Madrid, Taurus, 1956.

GaRiano, Carmelo, Análisis estilístico de los Milagros de Nuestra Señora de Berceo, $2^{\mathrm{a}}$ ed. corr., Madrid, Gredos, 1971. 
GARRIDO GALLARDO, Miguel Ángel, «Una clave interpretativa para tres recursos literarios fundamentales en los Milagros de Nuestra Señora: la alegoría, el protagonista absoluto y el final feliz», Revista de Filología Española, 1977, LIX, 1-4, 279-284.

GONZÁLEZ, Javier Roberto, «La alegoría arquitectónica en la novela sentimental y caballeresca (Cárcel de Amor - Cirongilio de Tracia)», Alfinge, 2003, 15, 27-56.

GONZÁLEZ, Javier Roberto, «La espada rota o dividida: su función en el Amadís de Gaula», Estudios Filológicos, 1997, 32, 73-81.

GONZÁLEZ, Javier Roberto, «El número como símbolo en la Edad Media latina», Stylos, 2000, 9/1, 89-118.

GONZÁLEZ, Javier Roberto, «Pautas para la caracterización del discurso profético ficcional como clase de texto: las profecías del Palmerín de Olivia», Incipit, 1998, XVIII, 107-158.

GONZÁLEZ, Javier Roberto, «Realismo y simbolismo en la geografía del Amadís de Gaula: la Ínsula Firme y sus dimensiones», Letras, 1993, 27-28, 15-30.

GONZÁLEZ, Javier Roberto, «Los sueños proféticos del Palmerín de Olivia a la luz de los Commentarii in Somnium Scipionis de Macrobio», Stylos, 1998, 7, 205-264.

Gregorius I Magnus, Dialogi, en Migne, J. P. (ed.), Patrologia Latina Database, s.1., Chadwyck-Healey INC., s.d., vol. LXXVII, cols. 381-385

Gregorius TuRonensis, Historia Francorum, en Migne, J. P. (ed.), Patrologia Latina Database, s.1., Chadwyck-Healey INC., s.d., vol. LXXI, cols. 174-175.

GREGORY, Tullio, I sogni nel medioevo, Roma, Edizione dell'Ateneo, 1985.

GUÉNON, René, La gran tríada, Barcelona, Ediciones Obelisco, 1986.

GUÉNON, René, «El paso de las aguas», en sus Símbolos fundamentales de la ciencia sagrada, Compilación póstuma establecida y presentada por Michel Vâlsan, Estudio preliminar de Armando Asti Vera, 3a ed., Buenos Aires, Eudeba, 1988, pp. 300-302.

GUÉNON, René, «El simbolismo del puente», en sus Símbolos fundamentales de la ciencia sagrada, Compilación póstuma establecida y presentada por Michel Vâlsan, Estudio preliminar de Armando Asti Vera, $3^{\text {a }}$ ed., Buenos Aires, Eudeba, 1988, pp. 336-339.

GuÉNON, René, Le symbolisme de la croix, 3 éd., Paris, Les Éditions Véga, 1970.

Helinandus Frigidi Montis, Chronicon, en Migne, J. P. (ed.), Patrologia Latina Database, s.1., Chadwyck-Healey INC., s.d., vol. CCXII, 1148, cols. 1037-1055.

Henricus SAlteriensis, Tractatus de Purgatorio Sancti Patricii Hibernorum Apostoli, en Migne, J. P. (ed.), Patrologia Latina Database, s.1., Chadwyck-Healey INC., s.d., vol. CLXXX, cols. 973-1004.

HOPPER, Vincent Foster, Medieval Number Symbolism, New York, Cooper Square Publishers INC., 1969.

Hugonis De S. Victore, Exegetica I, en Migne, J. P. (ed.), Patrologia Latina Database, s.1., Chadwyck-Healey INC., s.d., vol. CLXXV, cols. 22-23.

IMSCHOOT, P. van, «Profeta», en Diccionario de la Biblia, Edición castellana preparada por Serafín de Ausejo, Barcelona, Herder, 1964, cols. 1572-1582.

S. ISIDORI HISPALIENSIS EPISCOPI, Liber numerorum qui in Sanctis Scripturis occurrunt, en Migne, J. P. (ed.), Patrologia Latina Database, s.1., Chadwyck-Healey INC., s.d., vol. LXXXIII, cols. 179-199.

Kruger, Steven F., Dreaming in the Middle Ages, Cambridge, Cambridge University Press, 1992.

Lancelot, Roman en prose du XIII ${ }^{e}$ siècle, Edition critique avec introduction et notes par Alexandre Micha, Paris-Genève, Librairie Droz, 1978-1983, 9 vols.

LAUSBERG, Heinrich, Elementos de retórica literaria, Madrid, Gredos, 1983.

LE GOFF, Jacques, «Le christianisme et les rêves (II ${ }^{\mathrm{e}}-\mathrm{VII}^{\mathrm{e}}$ siècles)», en L'imaginaire médiéval. Essais, 2 éd., Paris, Gallimard, 1991, pp. 256-316.

LE GOFF, Jacques, «Los sueños en la cultura y la psicología colectiva del Occidente medieval», en su Tiempo, trabajo y cultura en el Occidente medieval, Madrid, Taurus, 1983, pp. 282-288. 
LÉON-DUFOUR, Xavier, Vocabulario de Teología Bíblica, Barcelona, Herder, 1967.

LesÊTRe, H., «Songe», en Vigouroux, F. (ed.), Dictionnaire de la Bible, Paris, Letouzey et Ané, 1912, vol. V, partie 2, cols. 1832-1834.

LEWIS, C. S., La alegoría del amor. Estudio sobre la tradición medieval, Buenos Aires, Eudeba, 1969.

LEwIS, Huw Aled, «The Vision of the Knight Túngano in the Literatures of the Iberian Peninsula», Speculum, 1997, 72/1, 85-99.

A.T. MACrobius, Commentarii in Somnium Scipionis, Edidit Iacobus Willis, Editio stereotypa editionis secundae, Stutgardiae et Lipsiae, in Aedibus B.G. Teubneri, 1994.

Mangenot, E., «Prophète», en Vigouroux, F. (ed.), Dictionnaire de la Bible, Paris, Letouzey et Ané, 1912, vol. V, partie 1, cols. 705-727.

Mangenot, E., «Prophétie», en Vigouroux, F. (ed.), Dictionnaire de la Bible, Paris, Letouzey et Ané, 1912, vol. V, partie 1, cols. 728-734.

Michel, A., «Prophétie», en Dictionnaire de Théologie Catholique, Paris, Letouzey et Ané, 1936, vol. 13, partie 1, cols. 708-737.

Michel, A., «Songe», en Dictionnaire de Théologie Catholique, Paris, Letouzey et Ané, 1936, vol. 14, partie 2, col. 2366.

NEHER, André, La esencia del profetismo, Salamanca, Sígueme, 1975.

PATCH, Howard Rollin, El otro mundo en la literatura medieval, México-Buenos Aires, FCE, 1956.

PÉREZ PRIEGo, Miguel Ángel, «Berceo y las postrimerías del hombre», en Studia in honorem Germán Orduna, Edición de Leonardo Funes y José Luis Moure, Alcalá de Henares, Universidad de Alcalá de Henares, 2001, pp. 523-533.

PORTAL, Frédéric, El simbolismo de los colores. En la Antigüedad, la Edad Media y los tiempos modernos, Palma de Mallorca, Sophia Perennis, 2000.

Post, Chandler Rathfon, Medieval Spanish Allegory, Westport, Greenwood Press Publishers, 1974.

ROBERTS, Edward A., y Bárbara PASTOR, Diccionario etimológico indoeuropeo de la lengua española, Madrid, Alianza, 1997.

SALA, Rafael, La lengua y el estilo de Gonzalo de Berceo. Introducción al estudio de la Vida de Santo Domingo de Silos, Logroño, Instituto de Estudios Riojanos, 1983.

SouvaY, Charles L., «Dreams», en The Catholic Encyclopaedia, New York, The Universal Knowledge Foundation INC., 1913, vol. 5, pp. 154-156.

Spearing, A. C., Medieval Dream Poetry, London-New York, Cambridge University Press, 1976.

SUÁREZ PALlaSÁ, Aquilino, «Sobre algunos aspectos lingüísticos y simbólicos del puente del romance viejo de la Doncella Guerrera», Letras, 1982, 4, 101-114.

TODOROV, Tzvetan, Simbolismo e interpretación, $2^{\mathrm{a}}$ ed., Caracas, Monte Ávila Editores, 1992.

ToDorov, Tzvetan, Teorías del símbolo, 3ª ed., Caracas, Monte Ávila Editores, 1991.

S. Tomás DE Aquino, Suma Teológica, Ed. bilingüe latín-castellano a cargo de Francisco Barbado Viejo O. P., Madrid, BAC, 1955.

WALSH, John K., «The Other World in Berceo's Vida de Santa Oria», en Hispanic Studies in Honor of Alan Deyermond, Madison, Hispanic Seminary of Medieval Studies, 1986, pp. 291-307.

WeBER DE KURLat, Frida, «La 'visión' de Santo Domingo de Silos. Berceo, Vida de Santo Domingo de Silos, cuartetas 224-251», en Estudios ofrecidos a Emilio Alarcos Llorach, Lisse, Peter de Ridder Press, 1978, III, pp. 489-505.

Fecha de recepción: 10 de noviembre de 2006

Fecha de aceptación: 26 de julio de 2007 